\title{
The Political Economy of Government Responsiveness: Theory and Evidence from India
}

\author{
by
}

\author{
Timothy Besley
}

and

\section{Robin Burgess}

We have received useful comments from Oriana Bandiera, Steve Coate, Torsten Persson and a number of seminar participants. We are grateful to STICERD for financial support. Grace Wong and Berta Esteve-Volart provided some excellent research assistance. 


\begin{abstract}
$\underline{\text { Abstract }}$
The determinants of government responsiveness to its citizens is a key issue in political economy. Here we develop a model based on the solution of political agency problems. Having a more informed an politically active electorate strengthens incentives for governments to be responsive. This suggests that there is a role both for democratic institutions and the mass media in ensuring that the preferences of citizens are reflected in policy. The ideas behind the model are tested on panel data from India. We show that public food distribution and calamity relief expenditure are greater, controlling for shocks, where governments face greater electoral accountability and where newspaper circulation is highest.
\end{abstract}

JEL Classification: D72, H11, H41, I38, 012, P26.

Key Words: government responsiveness, mass media, newspapers, political economy, political agency, political accountability, democracy, social protection, disaster relief, public food distribution

(C) The authors. All rights reserved. Short sections of text, not to exceed two paragraphs, may be quoted without explicit permission provided that full credit, including (c) notice, is given to the source. 


\section{Introduction}

Understanding what makes government responsive to citizens' needs is a key issue in political economy. It is particularly poignant in low-income countries where, in the absence of market opportunities, vulnerable populations rely on state action for their survival. A key issue is then what institutions - economic, social and political - can be built to enhance the effectiveness of the state in social protection. This paper lays out a framework for thinking about the issues and explores its empirical implications in an Indian context. Among other things, the approach highlights the importance of information flows about policy actions in increasing government responsiveness, particularly the role of mass media in creating an incentive for governments to respond to citizens' needs.

There is a large literature that emphasizes why the poor and vulnerable may not obtain the full attention of politicians even in a democracy where they have numerical strength. These groups are typically poorly informed and are generally less inclined to vote than richer and better educated citizens. A key question then is what institutions and mechanisms enable vulnerable citizens to have their preferences represented in policy. The approach laid out here does not rely on the vulnerable being in a majority for them to obtain political power. What is key is that they have enough electoral power to "swing" outcomes, otherwise politicians will not have an incentive to be responsive to their demands. However, this is not enough. In order to exercise their electoral power they must also perceive differences between candidates or parties as regards responsiveness. Mass media can play a key role here by enabling vulnerable citizens to monitor the actions of incumbents. This should give them some sense of about which politicians will protect them in the future and can be used as the basis of their voting decisions. Media development can therefore considerably strengthen incentives for incumbents to build reputations for being responsive as an informed electorate will have much greater power to punish unresponsive candidates than an uninformed electorate. Mass media thus capitalizes upon shared vulnerability among poor voters to ensure that they get receive greater policy attention.

It has long been recognized that the quality of government policy requires the development of key institutions. There is long tradition among social thinkers including Rousseau, Smith, Hobbes, Locke, Madison, Jefferson and Mill who have argued that press freedom is essential for citizens to make intelligent and well-grounded decisions about public affairs. The idea that a key role of the press is to inform the electorate is central to the political science literature on the role of mass media. ${ }^{1}$ Emphasis on the role of the media is also in tune with the idea that a strong civil society is an important aspect of economic development. The recent resurgence of interest in political economy, however, has paid little attention to the role of news media in influencing policy. ${ }^{2}$ There is also no firm empirical evidence in the literature of a link

\footnotetext{
${ }^{1}$ See, for example, Brians and Wattenberg [1996] and Mondak [1995].

${ }^{2}$ Stromberg $[2000]$ being a key exception.
} 
between media development and public policy.

In this paper we develop a model where mass media has a role in providing information that mitigates political agency problems. Having a more informed and politically active electorate strengthens incentives for governments to be responsive to the needs of vulnerable citizens. Using panel data for Indian states over the 1958-1992 period we then demonstrate that there is a robust link between media development and government responsiveness.

India is an interesting and important context for analyzing the political economy of government responsiveness. First, there are measurable shocks, such as droughts and floods, which hit vulnerable populations and vary over space and time. We exploit this variation in a panel of states between 1958 to 1992 to look at the factors that affect how responsive state governments are to these shocks. Second, state level programs allocate relief to populations that experience shocks. The relief measures we study include public food distribution and calamity relief expenditure. The institutions that administer relief are fairly similar across states - what differs is the political will to exploit them. As India is a federal democracy this allows us to study how political variables affect responsiveness. Third, India has a relatively free and independent press among countries at a similar level of economic development. Nonetheless, there are differences in newspaper circulation across the states. This variation will allow us to consider the role of news media in promoting government responsiveness.

We begin by showing that differences in government responsiveness are only weakly related to economic development of Indian states. However, politics does seem to matter. States that have higher historical turnout exhibit greater responsiveness to droughts and floods. We also find that the level of political competition and timing of elections exerts some influence on responsiveness. Finally we show that newspaper circulation is strongly and positively correlated with government responsiveness. Moreover, this comes primarily from publications that are not in the dominant languages - Hindi or English. This is consistent with the idea that regional presses play a key role in forcing state governments to respond to shocks.

The remainder of the paper is organized as follows. The next section lays out a theoretical structure through which to view the results. Section three describes the institutional context for the empirical test. Section four describes the data and methodology we employ to test the main ideas behind the model and presents the results. Section five concludes. 


\section{The Model}

\subsection{The Environment}

There is a continuum of citizens of size one who care about two issues: ideology and social protection. ${ }^{3}$ There are two time periods and no discounting. Citizens have a preferred ideology which we label as left and right: $k \in\{L, R\}$. A citizen of type $k$ receives a payoff $\phi_{k l}$ from a policy maker of ideology $l$. We assume that $\phi_{L L}-\phi_{L R}=\phi_{R R}-\phi_{R L}=\lambda>0$, where $\lambda$ is a measure of ideological polarization.

A fraction of the citizens is vulnerable to shocks and care about social protection. Let $j \in\{v, n\}$ denote a citizen's vulnerability where $v$ stands for "vulnerable" and $n$ for "non-vulnerable". In each period, a fraction $\beta \in[\underline{\beta}, 1]$ of the vulnerable citizens get hit by a shock to their consumption. We assume that each vulnerable citizen is equally likely to experience a shock so that $\frac{1+\underline{\beta}}{2}$ is the probability that any citizen is hit. The per-period utility function of a citizen of preference type $(k, j)$ is $y-f \delta_{j t}+\phi_{k l}$ with $\delta_{j t}=1$ if $j$ experiences a shock and $f>0$ denotes the size of the shock.

The fraction of citizens of type $(k, j)$ is denoted $\gamma_{j}^{k}$. We let $\gamma^{k}=\gamma_{n}^{k}+\gamma_{v}^{k}$ denote the fraction of the population with ideology $k$ and $\gamma_{j}=\gamma_{j}^{L}+\gamma_{j}^{R}$ the fraction with shock vulnerability $j$. We assume throughout that there are enough vulnerable citizens so that $\gamma_{v}^{k}>\left|\gamma^{L}-\gamma^{R}\right|$ for $k \in\{L, R\}$. This also requires that there be real political competition with the relative fractions of left- and right-wing citizens not being too far apart.

The government can act to protect the vulnerable citizens from the endowment shock. For simplicity, we assume that there are only two policies: protection $(\chi=1)$ and non-protection $(\chi=0)$. If the government chooses protection, this completely neutralizes the effect of the endowment shock for all of the vulnerable citizens. The entire cost of protecting the citizens is assumed to be borne by the policy maker. ${ }^{4}$ There are two possible (per capita) costs of protection: high $\left(c_{H}\right)$ and low $\left(c_{L}\right)$ with $c_{L}<c_{H}$. The shock is realized at the same time as $\beta$ is revealed and is low with probability $\rho$. We assume that the cost realization is private information to the government and that $\underline{\beta} c_{H}>\lambda>\underline{\beta} c_{L}$.

\subsection{Policy Determination}

There are two parties, denoted $A$ and $B$, that put up candidates for public office. Each party is comprised of a subset of non-vulnerable citizens with identical ideological preferences - party $A$ comprises left-wingers and party $B$ right-wingers. Candidates are party members and cannot commit to policies ahead of time. Each candidate is

\footnotetext{
${ }^{3}$ Ideology should be thought of as a catch-all for all government activity other than social protection.

${ }^{4}$ This is best thought of as being an effort rather than a financial cost - the latter falling on all citizens. If the cost affects taxes, then it would be possible for citizens to infer something about it. The analysis would go through providing taxes were not fully revealing of the cost shock.
} 
one of two types: compassionate $(C)$ or selfish $(S)$ denoted by $i \in\{C, S\}$. This characteristic is relevant only if the candidate wins office and is private information to the winning candidate. Compassionate policy makers protect the vulnerable regardless of the cost. Selfish policy makers will provide social protection only if it is in their interest to do so. Let $p$ denote the probability that any randomly selected policy maker of either ideology is compassionate.

Citizens who have been hit by a shock in period one observe the government's response. Whether it is observed by the remaining group of vulnerable citizens depends upon development of the media. We model this by assuming that a fraction $m$ of the vulnerable citizens is informed about government actions regardless of whether they experience a shock. Thus, the fraction of informed vulnerable citizens in period one is $\left(m+(1-m) \beta_{1}\right) \gamma_{v}$.

Electoral outcomes are also subject to shocks which can be interpreted as turnout shocks or uncertain changes in the electorate due to variations in the composition of the voting population over time. This is assumed to guarantee a range of conditions under which a policy maker must act without knowing whether or not he will win or lose a future election for sure. Let $\omega_{k}$ be the advantage that party $A$ has in the election in terms of underlying support. Then, we suppose that there is a pro-left shock $\varepsilon$ with distribution function $H(\varepsilon)$ where $\varepsilon \in[-E, E]$ such that party $A$ wins if and only $\omega+\varepsilon>0$. We assume that $H(\cdot)$ is symmetric and that $H(0)=\frac{1}{2}$. Thus, the probability that party $A$ wins is 1 if $\omega>E$ and zero if $\omega<-E$ and $1-H(-\omega)$ otherwise. Throughout, we assume that $H\left(-\left(\gamma_{L}-\gamma_{R}\right)\right) \in(0,1)$, which says that on a straight ideological fight, both parties have a positive chance of winning.

The timing of the policy process is as follows:

1. Parties choose their period one candidates.

2. Voters choose the period one incumbent.

3. Nature determines the period one shock $\left(\beta_{1}\right)$, whether the policy maker is compassionate, and the cost of action $\left(c_{1}\right)$.

4. The winning candidate chooses period one policy.

5. Parties choose their period two candidates.

6. Voters choose the period two incumbent.

7. Period two shock $\left(\beta_{2}\right)$ and cost of action $\left(c_{2}\right)$. If the policy maker is new, nature also determines whether or not he is compassionate.

8. The winning candidate chooses period two policy.

Parties are assumed to correctly calculate the election probabilities associated with different candidate pairs and take them into account when choosing candidates. 
Any election gives rise to a game between the two parties. Each party's strategy is the type of candidate it selects and its strategy set is the set of possible citizen types. Each party's payoff from any strategy pair is determined by the probability its candidate wins and its objective function. An equilibrium of the game in any time period is a pair of candidate choices, one for each party, that are mutual best responses.

\subsection{Equilibrium}

We will look for perfect Bayesian equilibria in which an incumbent maximizes his payoff given the beliefs of the voters. (These beliefs must be consistent with Bayes rule in equilibrium.) We solve the model backwards, beginning with the period two policy choice. This is straightforward - compassionate policy makers protect the vulnerable for all cost levels and sizes of shocks while selfish incumbents never do so.

In the period two election, the candidate of party $J$ is parametrized by a pair of characteristics $\left\{k_{J}, q_{J}\right\}$ where $k_{J}$ is the candidate's ideology and $q_{J}$ is the candidates "reputation", i.e., the probability that the candidate is compassionate. Nonvulnerable voters are not interested in $q_{k}$ since they do not value social protection. However, vulnerable voters may be prepared to vote for a candidate who is more likely to be compassionate as an insurance device against future shocks, even if that candidate does not share their ideology. The interesting case is where $\frac{1+\underline{\beta}}{2} f>\lambda-\mathrm{a}$ vulnerable citizen gets a large enough expected benefit from social protection relative to ideology. ${ }^{5}$

Vulnerable voters are interested in the reputational difference between the candidates of the two parties as represented by $\left|q_{A}-q_{B}\right|$. A group of vulnerable voters will support the candidate of the party that does not share their ideological preference if $\left|q_{A}-q_{B}\right|>2 \lambda /(1+\underline{\beta}) f$. Turning to period two voting behavior, if one party has a large enough reputational advantage, it will be supported by all of the voters who share its ideological preference plus the informed vulnerable voters from the other ideological group. Uninformed vulnerable voters will always vote their ideological preference. If $\left|q_{A}-q_{B}\right|<2 \lambda /(1+\underline{\beta}) f$, all voters vote their ideological preference. Given the randomness in elections, this determines a probability distribution over period two policy for any given set of candidate pairs.

Parties select candidates based on their reputations. Party members will choose the candidate that maximizes their chances of winning. Candidates are compassionate with probability $p$ unless they have been incumbents and their responsiveness has been observed. Any candidate who has not been responsive in period one is an electoral liability and will not be selected to run again. We assume that a candidate that has

\footnotetext{
${ }^{5}$ In the language of Besley and Coate (2000), this says that social protection for the vulnerable group is politically salient if there was contest between a known compassionate and a known selfish candidate in the period two election.
} 
been responsive is chosen to run again. ${ }^{6}$

We now consider the period one social protection decision. Let $q_{k}\left(\sigma_{1 k}, \kappa\right)$ denote the probability that a candidate of ideology $k$ is compassionate as a function of their period one social protection decision where $\sigma_{1 k}=1$ denotes choosing social protection in period one and $\sigma_{1 k}=0$ denotes not doing so. The variable $\kappa=1$ if the voter is informed and $\kappa=0$ if he is uninformed. An uninformed voter using Bayes rule learns nothing and hence will maintain their prior. Hence $q_{k}\left(\sigma_{1 k}, 0\right)=p$. An informed voter who observes that the incumbent is not responsive knows that he cannot be compassionate. Hence, $q_{k}(0,1)=0$. An informed voter who observes an incumbent being responsive will update according to:

$$
q_{k}(1,1)=\frac{p}{p+\operatorname{Pr}\left\{\sigma_{1 k}=1: S\right\}(1-p)},
$$

where $\operatorname{Pr}\left\{\sigma_{1 k}=1: S\right\}$ is the probability that a selfish politician will protect the vulnerable. The reputational gain from being responsive in period one is therefore

$$
p\left[\frac{(1-p)\left(1-\operatorname{Pr}\left\{\sigma_{1 k}=1: S\right\}\right)}{p+\operatorname{Pr}\left\{\sigma_{1 k}=1: S\right\}(1-p)}\right]
$$

This is largest when $\operatorname{Pr}\left\{\sigma_{1 k}=1: S\right\}$ is small. To describe the period one policy equilibrium, it is useful to define:

$$
\Gamma_{k}(\theta)= \begin{cases}H\left(-\left(\gamma^{L}-\gamma^{R}\right)\right)-H\left(-\left(\gamma^{L}-\gamma^{R}\right)-\theta\right) & \text { if } k=L \\ H\left(-\left(\gamma^{L}-\gamma^{R}\right)+\theta\right)-H\left(-\left(\gamma^{L}-\gamma^{R}\right)\right) & \text { if } k=H\end{cases}
$$

as the gain in the probability of being re-elected from attracting an extra fraction $\theta$ of voters. It is straightforward to show that $\Gamma_{k}(\cdot)$ is an increasing function.

We use this to characterize the period one social protection decision. The model may have multiple equilibria. There is always an equilibrium in which selfish incumbents do not protect the vulnerable and are not re-selected by their parties in period two. However, there is also the possibility of an equilibrium where selfish incumbents choose social protection, being motivated by reputational gains. An equilibrium of this form is described in:

Proposition 1 Suppose that $p\left[\frac{(1-p)(1-\rho)}{p+\rho(1-p)}\right]>\frac{2 \lambda}{(1+\underline{\beta}) f}$ and that a fraction $\beta_{1}$ of the vulnerable citizens are affected by the period one shock. Then, there is an equilibrium in which a selfish incumbent of type $k$ protects the vulnerable when the cost shock is low if and only if $\Gamma_{k}\left(\left(m+(1-m) \beta_{1}\right) \gamma_{v}^{-k}\right) \lambda>\beta_{1} c_{L}$.

We will refer to this as a responsive equilibrium. It describes a situation in which the incumbent protects the vulnerable whenever the cost shock is low and the size of the shock $\left(\beta_{1}\right)$ falls in an appropriate range.

\footnotetext{
${ }^{6}$ Clearly this is optimal if $\left|q_{\mathrm{A}}-q_{\mathrm{B}}\right|>2 \lambda /(1+\underline{\beta}) f$. Otherwise party members are indifferent.
} 
To generate a responsive equilibrium, a selfish incumbent must gain sufficient reputation from protecting the vulnerable. His incentive to do so hinges on two things. First, whether social protection becomes a salient issue for the vulnerable voters. The condition $p\left[\frac{(1-p)(1-\rho)}{p+\rho(1-p)}\right]>\frac{2 \lambda}{(1+\underline{\beta}) f}$ guarantees that this is the case. The second consideration is whether the expected gain from being responsive is large enough to offset the cost. The condition stated in the Proposition guarantees that this is the case. The left hand side is the increase in the probability of a candidate of ideology $k$ being elected and the right hand side is the cost of acting. This depends upon the fraction of informed vulnerable citizens of the opposite ideology that is informed, as this is the group of voters that an incumbent can attract by being responsive.

The Proposition reveals why the link between government responsiveness and the size of the shock is ambiguous. There are two effects. First, a larger group size raises the group that find out directly about whether the government is responsive. This will tend to increase the rewards from being responsive and thereby enhance the incentive to protect the vulnerable. Second, a larger affected group also raises the cost of being responsive as this is paid on a per capita basis. This will tend to reduce the incentive to respond. However, it is still possible for government to be responsive whether or not the media broadcast government actions in response to shocks.

Increasing access to mass media unambiguously increases the incentive to be responsive in this model as it increases the return to reputation building, i.e. increases $\Gamma_{k}\left(\left(m+(1-m) \beta_{1}\right) \gamma_{v}^{-k}\right)$. If everyone is informed about government responsiveness then the gain from being responsive does not depend upon the size of the shock at all.

The nature of responsive equilibria can be seen more clearly by considering an example where shocks to election outcomes are uniformly distributed on $[-E, E]$. Then, the expected gain from attracting a fraction $\theta$ more voters is:

$$
\Gamma_{k}(\theta)= \begin{cases}1 & \text { if } \theta>E-\omega_{k} \\ \frac{\theta}{2 E} & \text { if } \theta \in\left[-\left(\omega_{k}+E\right), E-\omega_{k}\right] \\ 0 & \text { if } \theta<-\left(\omega_{k}+E\right),\end{cases}
$$

where $\omega_{L}=\gamma^{L}-\gamma^{R}=-\omega_{R}$.

It is now straightforward to depict a responsive equilibrium in the Proposition graphically. Note that the critical value of $\theta$ is $\left(m+(1-m) \beta_{1}\right) \gamma_{v}^{-k}$, i.e., the fraction of informed vulnerable citizens. The graphs hold the fraction of citizens who have access to the media, $m$, fixed. We then plot gain from being responsive and the cost of being responsive as functions of $\beta$. We do so for party $A$ - the logic for party $B$ is basically the same. In Figure $1, \lambda>c_{L}$ and $\gamma_{v}^{R}>E-\omega_{k}{ }^{7}$ There is then a single cut-off value of $\beta$ above which the selfish incumbent will respond to the shock if the draw is $c_{L}$. In Figure 2 , there is a $\widetilde{\beta} \in[\underline{\beta}, 1]$ such that $\lambda=\widetilde{\beta} c_{L}$. In this case, there

\footnotetext{
${ }^{7}$ Both of the figures are drawn assuming that $\left(m+(1-m) \beta_{1}\right) \gamma_{\mathrm{v}}^{\mathrm{R}}<-\omega_{\mathrm{L}}-E$.
} 
are three ranges of $\beta$. For low $\beta$, the selfish incumbent is not responsive if the shock is low, while the incumbent is responsive if there is a middling shock. However, a high shock results in the government not being responsive. The last effect occurs because it is more costly for the incumbent to deal with extensive shocks. This simple analysis illustrates why government responsiveness to shocks may be non-linear and even non-monotonic. ${ }^{8}$

The effect of increasing access to the media can be illustrated in these diagrams: it moves the curve representing the benefit from responsiveness to the left. Hence, it unambiguously increases the range in which the government responds to shocks. However, this responsive effect is likely to be non-linear with media having more of an effect in certain ranges of the size of the shock.

The theoretical model also illustrates why competitive elections are likely to enhance government responsiveness. ${ }^{9}$ This can be illustrated in the diagram by varying the magnitude of $\omega_{L}$. If $\omega_{L}$ is close to a zero, then the left party has no intrinsic advantage in an election fought on ideological lines. Now consider what happens when $\omega_{L}$ becomes positive - it shifts the benefit curve to the right reducing the range of $\beta$ 's for which the government is responsive. The reasoning is clear - a government with a large advantage has less incentive to be responsive because this will not much affect the probability that it is re-elected. Parallel reasoning suggests that a government that is behind in the election (ideologically) will have a higher incentive to be responsive.

The model can also be used to address the link between polarization and government responsiveness. There are two effects heading in opposite directions which make this ambiguous a priori. The first operates through voting. An increase in ideological divergence raises $\frac{2 \lambda}{(1+\underline{\beta}) f}$, implying that the reputational difference between the candidates has to be much larger to make social protection a politically salient issue. This weakens the incentives for reputation building and makes it less likely that there will be a responsive equilibrium. The second effect arises from the fact that $\lambda$ affects the value from holding office. This enhances the incumbent's incentive to build a reputation. It is interesting to note that private rents would enhance government responsiveness by making reputation building more attractive.

Before turning to the empirical implications of the model, we complete the analysis of the remaining stages of the game. Turning now to the stage one election, the probability that party $A$ wins is $\psi\left(\gamma^{L}-\gamma^{R}\right)$ and party $B$ wins with probability $\left(1-\psi\left(\gamma^{L}-\gamma^{R}\right)\right)$. Party members are indifferent between all of the potential can-

\footnotetext{
${ }^{8} \mathrm{~A}$ couple of other cases are worth noting. The government is never responsive $\left(c_{\mathrm{L}}\right.$ is high enough) and always responsive - if $\underline{\beta} \gamma_{\mathrm{v}}^{\mathrm{R}}>\frac{1}{2}-\omega_{\mathrm{k}}+E$. In the latter case, there is no need to have media to have government responsiveness. Essentially, the political weight of the group that are affected is sufficient for the government to respond.

${ }^{9}$ This is related to an old debate in the political science literature initiated in large part by Key [1950] who argued that lack of political competition was on the whole detrimental to economically disadvantaged groups.
} 
didates who share their ideological view. The output of the model is a probability distribution over period one policy according to the outcome of the election in each period, the structure of shocks and the probability that compassionate and selfish incumbents are selected.

\subsection{Empirical Implications}

The theoretical model highlights a number of things that we should see in the data. Government responsiveness is likely to be a function of the severity of shocks. As shocks get bigger and affect a larger group of people the electoral cost of not responding to them increases. However, there is no need for the group to become a majority to gain political attention. The cost of not responding is also magnified by media attention. The cost of responding, however, also increases with the size of shocks. Thus, the relationship between responsiveness and the size of the affected group is not clear a priori and we can investigate this in the data.

If governments are not inherently benevolent we would expect politics to matter for responsiveness. Greater political participation by citizens will tend to strengthen electoral incentives for incumbents to be responsive. We will be looking at this issue by examining how electoral turnout affects responsiveness to shocks across Indian states. $^{10}$ With greater turnout the power of vulnerable citizens to swing elections is greater and knowing this incumbent politicians are likely to be more responsive to their need for social protection. We might also expect responsiveness is greatest where political competition is most intense and ruling parties are least secure as regards electoral margin. To measure this, we will look at the absolute difference between the proportion of seats gained by the two dominant parties in a state.

Though not strictly predicted by the theory it will also be interesting to examine whether governments are more responsive nearer election times. This would be expected if citizens are more likely to react to more recent events when they make their voting decisions. Finally we would want to examine how polarization within the electorate affects responsiveness. Theory on this matter is ambiguous, however,

\footnotetext{
${ }^{10}$ This can be brought formally into the model laid out above. Suppose that there are two shocks to electoral outcomes - the shock $\varepsilon$ laid out above which is biased in favor of the $L$ party and a shock $\sigma(\in(\underline{\sigma}, \bar{\sigma}) \subset(0,1))$ which is unbiased. Let the density of $\sigma$ be $k(\sigma)$. Then party $L$ wins if

$$
\sigma\left(\omega_{\mathrm{L}}-\omega_{\mathrm{R}}\right)+\varepsilon>\frac{1}{2}
$$

Suppose that $H(\varepsilon)$ is uniform. Then if $\gamma_{\mathrm{v}}^{-\mathrm{k}} \in\left[\frac{1}{2}-\sigma^{*} \omega_{\mathrm{k}}-E, \frac{1}{2}-\sigma^{*} \omega_{\mathrm{k}}+E\right]$ for $k \in\{L, R\}$ where $\sigma^{*}=$ is expected turnout, then

$$
\Gamma_{\mathrm{k}}(\theta)=\frac{\sigma^{*} \theta}{2 E}
$$

is the expected gain from being responsive which is increasing in turnout. Thus responsiveness is increasing in expected turnout provided that there is enough noise in elections.
} 
it would be interesting to see which way it goes in the data. Where society is more polarized along ideological lines, policy performance may have less of an impact in terms of leading voters to switch their votes to more responsive incumbents. ${ }^{11}$ This will tend to weaken incentives for politicians to build reputations. Higher levels of ideological polarization, on the other hand, will tend to increase the value of holding office. This enhances the incumbent's incentive to build a reputation. We analyze this issue in the data by looking at how caste polarization affects government responsiveness.

Our theory also suggests that responsiveness should be greater where information flows are more developed. Availability of mass media should permit vulnerable citizens to learn about incumbents reputations. This should affect their voting decisions and strengthen incentives for politicians to respond to shocks. To look at this, we will examine how newspaper circulation, in the aggregate and broken down by language, affects government responsiveness.

\section{Institutional Context}

We use data from the sixteen major Indian states for the period 1958-1992 to test the implications of the theory. India is an important case study for analyzing the political economy of responsiveness. It is home to a large vulnerable population which is regularly buffeted by natural shocks including droughts, floods, earthquakes and cyclones. ${ }^{12}$ Over time, measures including public food distribution, calamity relief expenditure and public works projects have been developed to deal with these shocks. India is a federal democracy and popularly elected Indian state governments play a key role in social protection. Press activity in Indian states exhibits significant time-series and cross-sectional variation.

The development of policies to deal with natural shocks in India is closely intertwined with famine prevention. Though famine relief has a long history, ${ }^{13}$ Dreze (1991) points out that the emergence of a coherent and effective strategy to deal with the threat of famine is relatively recent. For a large part of its history the state in India had limited success in dealing with these crises, leading to the death of millions (see Sen, 1981; Dreze 1991; Dreze and Sen, 1989). Frequent and severe famines during both the 18th and 19th centuries were a major source of concern to the British

\footnotetext{
${ }^{11}$ The model also predicts that an incumbent should be less responsive were he not subject to re-election incentives. While there are no term limits in India to test this with, it is interesting to note that Besley and Case (1995) find that US states where the governor faces a binding term limit are less responsive to natural disasters - a finding which is consistent with the theory presented here.

${ }^{12}$ Over the period an average of about half the population fell below the poverty line.

${ }^{13} \mathrm{~A}$ treatise ascribed to Kautilya written over two thousand years ago recommends that "when famine threatens the king should "insitute the building of forts or water-works with the grant of food, or share (his) provisions (with them), or entrust the country (to another king). (Cited by Dreze (1991)).
} 
Administration which came to power in 1858. This led to the setting up of Famine Commissions, most notably that of 1880, which produced a set of Famine Codes detailed guidelines for local administrators about the anticipation, recognition and relief of famines. ${ }^{14}$ The 1880 Report represented a turning point in the history of calamity relief in India. For the first time there was an effective nationwide strategy for dealing with the threat of famines and other natural calamities. As Dreze (1991) points out such was the success of this strategy that the history of famine prevention in India may be divided into the a pre- 1880 period characterized by frequent and severe famines and a post-1880 period where there were few famines. ${ }^{15}$

Famines, however did still occur during the post 1880 British period most notably during 1896-1897, 1899-1900 and 1943. Analysis of these famines suggest that relief guidelines were, on occasion, ignored. ${ }^{16}$ The existence of these guidelines clearly did not guarantee their early and energetic implementation. This points to a need to have mechanisms in place for triggering relief measures. ${ }^{17}$ Politics and the media can play a role here. Following Independence in 1947, the arrival of representative democracy and the rise of mass media helped to strengthen accountability within the calamity relief system. India became a federal democracy and elected state governments assumed responsibility for calamity relief. Elections to state legislative assemblies therefore became a mechanism through which politicians could be held accountable for responding to droughts or floods occurring within their jurisdictions. India also witnessed an explosion in newspaper circulation during this period with much of this growth being accounted for by regional papers published in languages other than English or Hindi (see Jeffrey, 2000). The newspaper industry that developed was distinguished from the bulk of other low income countries by being relatively free and independent. ${ }^{18}$ The press in India has been ascribed a major role in monitoring the actions of politicians and in ensuring their responsiveness to droughts and floods which occur at frequent intervals. Ram (1991: 186) describes it's role in averting crisis: "Over time, it has tended to bring out the facts in the field with elements of vivid descriptive and human interest detail; and to expose the failure of government authorities to recognize the problem, its causes and early symptoms, and to respond quickly and adequately in

\footnotetext{
${ }^{14}$ The Famine Codes emphasized the need for local administrators to look for signs, such as large drops in food production and increases in food prices, which signal an impending crisis and then to respond quickly through the setting up of massive public works and relief centres to prevent the onset of famine. The Famine Codes still constitute the backbone of calamity relief policy in India today.

${ }^{15}$ The development and extension of communication (particularly railways) also enhanced the capability of the British to deal with the threat of famine (see Dreze, 1991).

${ }^{16}$ For example during the Bengal Famine of 1943 where between 1.5 and 4 million people lost their lives (see Sen 1981).

${ }^{17}$ The seminal analysis of the Bengal Famine of 1943 by Sen (1981) pointed to how political factors led to the Famine Codes being deliberately ignored.

${ }^{18}$ Note that this is in strict contrast to TV and radio which were mainly under state control hands during the 1958-1992 period. In contrast only $2 \%$ of newspapers in India are owned by central and state governments.
} 
terms of crisis prevention, management, and relief." ${ }^{19}$ Massive expansion in the public distribution system which has involved large-scale government involvement in the procurement, storage, transportation and distribution of food grains also enhanced the governments ability to respond to shocks. Though this system has been inadequate to the challenge of reducing mass-poverty in India its role in preventing famines is well recognized (see Dreze, 199; Alhuwalia, 1993).

Table 1 provides means and standard deviations of the main variables used in the paper. $^{20}$ These are averaged for the 1958-1992 period and arrayed by state. Table 1 demonstrates there is significant variation across the Indian states in terms of government responses, severity of shocks, political outcomes and newspaper circulation. In the first and second columns of Table 1 we consider two dimensions of government responses to natural shocks. The total amount of food grains per capita distributed via the public distribution system in each state is our drought response variable. The share of calamity relief expenditure in net state domestic income is our flood response variable. Public distribution of food per capita varies seven fold between Madhya Pradesh (low) and Kerala (high). Calamity relief expenditure never constitutes much more than half a percentage point of total state GDP but nonetheless exhibits pronounced variation ranging from $0.58 \%$ in Orissa, which is particularly prone to natural disasters, to $0.16 \%$ in Tamil Nadu. The shocks that we consider are food grain production per capita as an indicator of the severity of a drought shock and the real value of crop damage caused by floods as an indicator of the severity of a flood shock. The third and fourth columns of Table 1 indicate that there is pronounced variation both in food grain production per capita and in the value of crop damage from floods. To better capture the notion of shocks in the data we have also graphed out these variables as deviations from (state specific) means for each of the states. These results are shown in Figures 3 and 4 and make it clear that certain states are drought prone in terms of experiencing large fluctuations in food grain productions per capita whereas others are flood prone in terms of regularly experiencing significant flood related crop damage.

As is apparent from Table 1 there is also pronounced variation across states in terms of the functioning of state level political systems. Electoral turnout in elections to state level assemblies (Vidhan Sabha) over the period is high $(60.9 \%$ ) indicating that the Indian population has been politically active as a whole. There is, however, considerable variation across states. Orissa for example registered a turnout of $44.9 \%$ over the period whereas the corresponding figure for Kerala was $77.6 \%$. Political competition has been intense over the period. Congress has been the dominant party over the period though in each and every state there has been numerous switches

\footnotetext{
${ }^{19}$ The lack of democracy and of freedom of information have been pointed to as reasons behind why China experienced a major famine between 1958 and 1961 with excess mortality figures ranging between 16.5 and 29.5 million whereas India has not experienced a major famine in the postIndependence era (see Dreze and Sen, 1989).

${ }^{20}$ Detail on the construction and sources of these variables are contained in a Data Appendix.
} 
between Congress and various competitors (see Data Appendix). Over the period the absolute difference between proportion of seats occupied by Congress and its main competitor(s) has been smallest for Kerala (0.15) indicating the most intense political competition and largest for Maharashtra (0.67) denoting the least political competition. As regards polarization, scheduled caste and scheduled tribe (SC/ST) individuals comprise about $22.1 \%$ of the Indian population over the period, states however vary in terms of the concentration of these individuals ranging from $8.1 \%$ in Jammu and Kashmir to $38.5 \%$ in Orissa. Variation along these different dimensions will be exploited to examine how politics affects government responsiveness.

Our key proxy of media development is newspaper circulation both in aggregate and broken down by language of circulation. While crude, we believe that it is likely to capture well the flow of information about policy to citizens. A key observation is that the Indian press, unlike many others in the developing world is both free and active. ${ }^{21}$ The freedom of the Indian press is central to its ability to elicit timely and effective government responses following natural shocks such as droughts and floods (see Ram, 1991). ${ }^{22}$ Press freedom can be contrasted with other forms of media in India, such as radio and television, which for the bulk of the period 1958 to 1992 have been under strict government control. Ram (1991: 189) notes that the pluralism and independence of the press is "in strict contrast to the regressive monotony of the and the narrowly construed propagandistic tone of state-owned and state-regimented television and radio". Figure 5 makes clear that the level of media penetration varies markedly across space and time. This variation will be exploited in our econometric analysis. Figure 5 shows that circulation in Kerala is both highest and has grown most quickly across the period. Circulation levels are also relatively higher in progressive states such as Tamil Nadu, Maharashtra, Karnataka, Punjab and West Bengal whereas they are low in backwards in states such as Bihar, Uttar Pradesh, Orissa, Madhya Pradesh and Rajasthan giving the impression that media development is linked to social development. However, the correlation with state income is not particularly strong. Less surprisingly, it is closely related to literacy. ${ }^{23}$ Jeffrey (2000) notes that much of the growth of newspaper circulation is accounted

\footnotetext{
${ }^{21}$ Ram (1991: 188) underlines this point by stating that "the Indian press is widely regarded as the most pluralistic, the least inhibited and the most assertive or independent in all the Third World".

${ }^{22}$ One way to look at the issue of plurality and independence of the Indian press is to look at ownership structure. Over the period 1958-1992 only a very small fraction (roughly 2\%) of newspaper titles are owned directly by central or state government. Ownership of the remainder is spread across a variety of owners who are quasi-independent from the state with the bulk of titles (roughly 70\%) being owned by private individuals (Press in India, Annual Report of the Registrar of Newspapers for India, Ministry of Information and Broadcasting, Government of India).With an ownership structure as independent and plural as this it is perhaps not surprising that the press in India plays a central role in highlighting government failure to respond to crisis situations.

${ }^{23}$ The correlation coefficient between net state domestic income per capita and newspaper circulation per capita is 0.27 compared to a correlation coefficient between the literacy rate and newspaper circulation of 0.81 .
} 
for by the rise of regional papers published in languages other than English in Hindi. From Table 1 it is clear that for the bulk of state newspaper circulation is now accounted for by these newspapers which may have a stronger focus on local issues than the nationals. ${ }^{24}$

\section{Empirical Analysis}

\subsection{M ethod}

Our basic method is to run panel data regressions for states $i$ and years $t$ of the following form:

$$
g_{i t}=\alpha_{i}+\beta_{t}+\delta s_{i t}+\gamma\left(s_{i t}\right)\left(z_{i t}\right)+\phi z_{i t}+u_{i t}
$$

where $\alpha_{i}$ and $\beta_{t}$ are state and year fixed effects and $z_{i t}$ is a vector of economic, political and media variables which we might expect to affect government responsiveness $\left(g_{i t}\right)$. This specification allows the right hand side variables $z_{i t}$ to enter both with level effects affecting the permanent level of government responsiveness and as interaction terms with the shock. Hence, we can estimate both average and marginal responses to shocks.

We begin by investigating how measures of shocks $\left(s_{i t}\right)$ affect different dimensions of government responsiveness $\left(g_{i t}\right)$. We will isolate two "shock-response" systems for further analysis. We then include some economic controls as elements of $z_{i t}$, such as state domestic income, level of urbanization and population density which might capture the technological capacity of state governments to respond.

We then extend the $z_{i t}$ vector to include media and political variables. These include newspaper circulation, electoral turnout, political competitiveness, caste polarization and timing of elections. Taking the economic, political and media variables together will allow us to build up a picture of what factors drive states to be more active in areas such as food distribution and calamity relief while controlling for the impact of shocks. Drawing from the theory, the coefficients on the media and political variables are of particular interest as we would not expect them to have any impact for purely benevolent governments.

Having examined these level or average effects we then turn to analyze the marginal effects of political and media variables $\left(z_{i t}\right)$ on responsiveness by interacting them with shock variables $\left(s_{i t}\right)$. Coefficients on the interaction terms $\left(s_{i t}\right)\left(z_{i t}\right)$ tell us, for a given shock, whether having higher newspaper circulation, greater political participation or competition, higher caste polarization or proximate elections enhances or depresses responsiveness. This analysis which is motivated by the theory hinting at the possibility of non-linear responses allows us to trace out how state governments have

\footnotetext{
24 "Other" includes newspapers published in Assamese, Bengali, Gujarati, Kannada, Kashmiri, Konkani, Malayalam, Marathi, Manipuri, Nepali, Oriya, Punjabi, Sanskrit, Sindhi, Tamil, Telugu and Urdu. Typically only one of these languages is prevalent in a given state.
} 
responded to specific shock episodes either by distributing food or via the provision of calamity relief.

Droughts and floods occur at regular intervals in Indian states during the 19581992 period. As these natural shocks are relatively exogenous events, depending mainly on the vagaries of climate, our marginal analysis which focuses on interpretation of coefficients on $\left(s_{i t}\right)\left(z_{i t}\right)$, makes us more confident that we are capturing the impact of political and media variables on responsiveness as opposed to the effect of correlated variables omitted from the regression. The final empirical efforts investigate media and responsiveness in greater detail, worrying about possible reasons why newspaper circulation could be correlated with the error in the responsiveness equation.

\subsection{Results}

\subsubsection{The Shock-R esponse R elationship}

We consider two social protection measures collected from independent sources: per capita public food distribution and calamity relief expenditure expressed as a share of net state domestic income. Our measures of shocks are food grain production and the real value of crops damaged by floods. We begin in Table 2 by showing that these shocks do invoke public responses. Column (1) indicates that public food distribution responds to drops in food grain production but not to crop damage caused by floods, suggesting that this is mainly a response to droughts. Column (4) indicates that calamity relief expenditure responds to crop damage but not to drops in food grain production indicating that it is mainly a response to floods. This, therefore, gives us two distinct shock-response systems to explore further in the data: food production-food distribution linkages and flood damage-calamity relief linkages. We present separate panels for each of these and compare the results.

Columns (2) and (5) examine the structure of responsiveness in more detail. We construct dummy variables for whether an observation for a particular state and year is in the $0-25,25-50,50-75$ or 75-100 percentile of the state specific distribution of food production or crop damage. Column (2) suggests that the impact of food production on public food distribution is non-linear being significant for observations below the state median and insignificant above. Equality of coefficients is clearly rejected by the $F$ test shown at the bottom of column (2). Henceforth, therefore, we will use a "food shock" indicator variable which is equal to one to one if food production in that year is below the state's sample median, and is zero otherwise. The result in column (3) implies that having a food shock measured in this way leads to a $20 \%$ increase in food distributed through the public distribution system.

Column (5) shows that the impact of flood crop damage on calamity relief expenditure is linear with all parts of the distribution having a similar and significant impact on policy. The $F$ test confirms that we cannot reject the equality of the coefficients. Henceforth, therefore, we will use the level of flood crop damage as our 
measure of the shock. The coefficient in column (6) implies that a $1 \%$ increase in the real value of crop damage caused by a flood leads to a $23 \%$ increase in calamity relief expenditure.

\subsubsection{B asic Results}

Table 3 presents our baseline results on the determinants of responsiveness in Indian states. In addition to including our shock indicators, columns (1) and (3) introduce income per capita, urbanization and population density as proxies for the capacity of governments to respond. For example, we would expect richer states to have more developed response mechanisms. Population density and urbanization should also reflect the ease of reaching target populations.

We find no impact of state income on public food distribution and the fraction of state income devoted to calamity relief tends to decline with state income. ${ }^{25} \mathrm{Popu}-$ lation density is insignificant in both regressions and urbanization is insignificant in the calamity relief regression. Column (1) suggests that more urbanized states have higher levels of public food distribution. This effect, however, disappears when we control for media and political variables in column (2). Economic factors appear to have a limited impact on government responsiveness. Richer, more urbanized or more densely populated states do not appear to be more responsive. This suggests that the technological capacity to respond may not be the key determinant of responsiveness. And this leads us to examine a range of factors, ranging from mass media to politics, which may affect incentives for government to be responsive to the social protection needs of citizens.

Columns (2) and (4) add newspaper circulation and political factors to explain the average level of responsiveness. They show that, after controlling for both shock levels and basic economic and political indicators, newspaper circulation is positively and significantly correlated with both food distribution and calamity relief. Thus, those states that have higher levels of media development are also more responsive (on average) in terms of public food distribution and calamity relief expenditure. A $1 \%$ increase in newspaper circulation is associated with a $2.4 \%$ increase in public food distribution and a $5.5 \%$ increase in the share of public expenditures devoted to calamity relief. These are large and significant effects. Overall, this is consistent with our theory in which development of mass media may improve information dissemination and make a government more responsive in protecting the vulnerable.

Columns (2) and (4) also include a range of political factors that might be correlated with responsiveness. Electoral turnout is a reasonable proxy for political activism and hence might enhance electoral incentives to protect vulnerable citizens. The level of political competitiveness proxied by the electoral margin between the ruling party and its main competitor might also be expected to affect incentives to respond. The fraction of the population classified as scheduled caste/scheduled tribe

\footnotetext{
${ }^{25}$ This may be due to poorer states being more prone to natural disasters.
} 
is a rough measure of polarization in Indian society. ${ }^{26}$ We also include an election dummy, equal to one if it is an election or pre-election year in a given state. While, not strictly predicted by the theory, it is possible that governments are more responsive near elections if citizens have better memories about recent events.

The results show that, controlling for shocks, electoral turnout rates in Indian states do not exert a direct effect on either levels of public food distribution or calamity relief expenditures. Where ruling parties are more secure due to there being larger electoral margins and less political competition we tend to see higher levels public food distribution. This is not the case for calamity relief. We also observe that state governments are more responsive in terms of public food distribution during election and pre-election years. (The coefficient corresponds to a $15 \%$ increase in public food distribution in election and pre-election years.) This effect is not present for calamity relief expenditures. Having a higher fraction of scheduled caste/scheduled tribe in the population does not appear to affect average levels of food distribution or calamity relief. The results suggest that, in particular for public food distribution, politics matter. Governments who are threatened either due to there being a close competitor or due to the proximity of an election tend to be more responsive. ${ }^{27}$ In both columns (2) and (4) we find that both the shock and newspaper circulation variables are positive and significant and are robust to the inclusion of both political and economic controls.

These baseline results support the notion that both politics and media development are correlated with government responsiveness. Moreover, parallel findings emerge from studying the effects of food production shocks on public food distribution (columns (1) - (2)) and the effect of crop damage on calamity relief expenditure (columns (3) - (4)). This is true even though these data were collected from entirely independent sources (see the Data Appendix). The effect of economic variables are less pronounced. Only state per capita income exerts a negative influence on calamity relief. All other coefficients on the economic control variables are insignificant. This suggests that the capacity to respond may be less important than there being media and political channels in place through which citizens can influence the actions of politicians in order to ensure that their preferences are reflected in policy.

In summary, we find that, across the board, higher newspaper circulation levels are associated with higher average responsiveness. Election cycles and political competitiveness have a strong impact on public food distribution whereas electoral turnout and polarization do not appear to affect responsiveness when introduced as

\footnotetext{
${ }^{26}$ The Hindu caste system assigns every individual to a caste and each caste occupies a determinate position in a hierarchical scale of ranks. Between two to three thousand castes exist, of which 779 of the most socially disadvantaged castes are identified by the Government of India as scheduled castes. Scheduled tribe refers to members of India's indigenous tribal population. In the 1991 census about $25 \%$ of population is identified as scheduled caste or scheduled tribe of which about two thirds is made up of scheduled caste (Pande, 1999).

${ }^{27}$ This idea is consistent with the empirical evidence from the U.S. by Holbrook and van Dunk [1993].
} 
a level. Overall, it seems reasonable to account for these results with a model that emphasizes the importance of government incentives.

\subsubsection{Political Determinants of $M$ arginal Responsiveness}

So far, we have only considered average effects. However, the theory suggests the possibility that political effects can also change marginal responsiveness to a shock. We examine this by interacting our political and media variables with shock variables for both kinds of government responsiveness as well as including the level effects. In presenting these interactions, the food shock variable that we use is the annual deviation of food grain production per capita from the state specific median value for the period 1958-1992. ${ }^{28}$

These results are displayed in Table 4. In columns (1) and (4) we see that, while lagged turnout has no impact on average responsiveness, it does have an impact on marginal responsiveness for both kinds of public action. As food production falls below its state specific median or as the value of crop damage caused by flooding increases, having higher turnout in the previous election tends to increase the responsiveness of governments to these shocks. This is consistent with the idea that electoral threats will tend to be greater where states have a greater tradition of turning out to vote.

In columns (2) we see that where political competition is less intense as measured by there being a larger gap between the number of seats occupied by the ruling party and its main competitors then governments tend to be less responsive to the poor in terms of public food distribution. We find no comparable effect for calamity relief in column (6). Coefficients on terms where political competitiveness is interacted with shock variables are both insignificant. Thus while greater political competition seems to enhance average responsiveness as regards food distribution it does not appear to make state governments in India more responsive to specific drought and flood shocks.

Columns (3) and (7) examine level and interaction terms for caste polarization effects. Level effects remain negative and insignificant for both food distribution and calamity relief suggesting that polarization does not affect how active states are, on average, in these areas of social protection. In column (5) the interaction term is negative and significant signalling that greater fragmentation along caste or tribal lines tends to depress the responsiveness of state governments to flood shocks. ${ }^{29}$ This re-

\footnotetext{
${ }^{28}$ Using the food shock dummy often resulted in including a variable that was highly collinear with the political variables and, while delivering similar findings, could not be considered reliable. Interactions generated using the deviations from the median measure are not problematic in this sense. However, collinearity concerns do make it unreliable to include multiple interaction terms in the same regression. Hence, we only investigate these ad serium.

${ }^{29}$ This may be because in more polarised states citizens vote more on ideological grounds as opposed to on the observed actions of incumbents thereby weakening incentives for politicians to build reputations for being responsive. This is consistent with evidence that voting in India has
} 
sult resonates with a growing literature which suggests that polarization along ethnic or income dimensions tends to weaken collective action and lower economic performance. ${ }^{30}$. The interaction term in column (3), however, goes in the opposite direction suggesting that states with greater caste polarization tend to be more responsive to specific food production shocks. This may reflect the success of low caste groups in galvanizing political support to increase flows of food grains through the public food distribution system during periods of drought. Like the predictions emerging from the theory these results are ambiguous. They are, nonetheless, interesting as they suggest that the degree of polarization in a state does affect marginal responsiveness.

Table 4 also introduces an interaction term for the election and pre-election year effects. We see that these variables interacted with our shock variables have no influence on responsiveness. Being in an election or pre-election year does not seem to make politicians more responsive on the margin to shocks. In column (3) we see that being in an election or pre-election year, however, does continue to increase the amount of food distributed per capita on average suggesting that this may be a populist measure.

Taken together we find that political effects are more pronounced for the food distribution than for calamity relief. This is understandable given that public food distribution system is a larger, more politicized operation. Ration shops which operate during both shock and non-shock periods are viewed as key source of social protection for the poor and vulnerable against both chronic and transitory food insecurity and are a subject of intense political debate and scrutiny. In contrast, calamity relief operations by being both limited to shock periods and benefiting a smaller fraction of the electorate are likely to attract relatively less political attention.

Inclusion of the various interaction terms does not lead to significant changes in the other included regressors. In particular, the coefficient on newspaper circulation per capita remains robustly positive and significant.

\subsubsection{M edia and Responsiveness}

In this section, we will explore the relationship between newspaper circulation and government responsiveness in greater detail. Columns (1) and (4) of Table 5 allow our proxy for media development to have both a marginal and an average effect, the latter being estimated by interacting newspaper circulation with shocks. As in Tables 3 and 4 the average effect of newspaper circulation remains positive and significant. The coefficients on the interaction terms are also positive and significant for both systems, suggesting that the response to a shock is greater on the margin when newspaper circulation is higher. Where the actions of politicians are more

traditionally been done along caste (high caste, SC/ST), party (Congress, non-Congress) or family (Ghandhi, non-Ghandhi) lines. In this situation there will be less swing voters and the incentive for a candidate to build a reputation by responding to crises is weakened.

${ }^{30}$ See, for example, Alesina, Baqir and Easterly [1999], Miguel, [1999], la Ferrara, [1999] and Narayan and Pritchett [1998]. 
transparent due to the actions of the press we tend to see them being more active in terms of implementing policies which accord some degree of protection to vulnerable citizens against shocks. The results are striking as we see the same pattern for both average and marginal effects across two separate shock-response systems based on different data sources.

To give some idea of the magnitudes involved we find that a $10 \%$ drop in food production is associated with a $1 \%$ increase in public food distribution in states which are at the median in terms of newspaper circulation per capita. However, for states that are in the $75 \%$ percentile in terms of newspaper circulation per capita we find that a $10 \%$ drop in food production is associated with a $2.28 \%$ increase in public food distribution. These are economically meaningful responses.

These marginal results are in line with our theory. The fact that we include an array of other controls makes it more likely that this is indeed a media effect rather than a proxy for some other omitted variable. However, the possibility that there is some third factor driving responsiveness and newspaper circulation is a reasonable concern and the remainder of this section explores this issue further by exploring the robustness of our media effects to a number of further tests.

We begin by looking at newspaper circulation disaggregated by language. India is a linguistically diverse country and the large array of languages in which newspapers are published is symptomatic of this. In addition to the 'national' languages English and Hindi we have information on the circulation of newspapers published in Assamese, Bengali, Gujarati, Kannada, Kashmiri, Konkani, Malayalam, Marathi, Manipuri, Nepali, Oriya, Punjabi, Sanskrit, Sindhi, Tamil, Telugu and Urdu. Most of these languages are specific to a particular state. It is quite possible that newspapers published in local languages are more effective in informing potential voters and eliciting government responsiveness. This might be the case if the poor and vulnerable are able to read newspapers in local languages but not in either Hindi or English. Newspapers published in local languages might also focus more on local, state specific crises relative to national papers which have to satisfy a wider readership. It is, however, difficult to think of reasons why language of publication should be correlated to some omitted variable which might be driving the aggregated results shown in columns (1) and (4). We, therefore, supplemented our data set with information on newspaper circulation by language. This enables us to see whether the publication language affects government responsiveness. For the nineteen languages on which we have circulation data on English and Hindi are national in scope whereas the other seventeen tend to be specific to particular states. We have therefore aggregated this information into three groups; English, Hindi and other which captures a range of regional papers published in seventeen 'local' languages. This categorization allows us to investigate whether regional, local language presses are more effective than national presses in creating incentives for state level politicians to respond to local livelihood crises.

It also mitigates concerns that our media results are being driven by some omitted 
'social development' variable. Patterns of the evolution of newspaper readership vary considerably by state so the source of identification of the media effect is potentially rather different when we use the language specific data. For example, the state of Kerala that has experienced a rapid increase in newspaper circulation has mainly done so by increasing circulation of titles in local languages. Overall, circulation of English newspapers has not increased over the period while Hindi newspapers have increased their circulation by $5.8 \%$ per annum. However, this varies from a $24 \%$ annual growth rate in Assam to a 17\% annual reduction in Karnataka. Overall, non-English, non-Hindi newspaper circulation grows at $1.7 \%$ with a $7 \%$ growth rate in Bihar and small declines in three states.

To examine the hypothesis that language of publication might affect responsiveness we allowed three categories of newspaper circulation to enter separately in our basic regression. The results are given in Table 5. In columns (2) and (4) we find that, controlling for shocks and our economic and political controls, we find that it is the regional local language press, captured under "other" newspaper circulation, that is driving our results. Neither English or Hindi circulation are associated with higher levels of food distribution or calamity relief at the state level. When we introduce our three categories of newspaper circulation interacted with the shock variables we get the same pattern of results (see columns (3) and (6)). It is "other" newspaper circulation entered on it own or interacted with the shock which drives up responsiveness. This congruence of average and marginal effects suggest a focus on the role of regional presses which disseminate information in local languages that drive both average levels of responsiveness as well as responsiveness to specific drought and flood shocks.

These findings make sense as we are studying responses by state governments where the role of a more localized press is likely to be more important than the national press. In many ways the story of the press media in India in the postIndependence era is one about newspapers being increasingly published in the statespecific local languages spoken by the bulk of Indians (Jeffrey, 2000). The fact that local language papers are both read by the poor and vulnerable and have a highly localized focus helps to explain why it is these newspapers that are driving our results and not the newspapers published in either English or Hindi. It is these regional presses which appear to lie at the heart of why media development encourages government responsiveness in Indian states.

These results are also much less likely to be driven by a monolithic omitted "social development" variable which is correlated with government responsiveness and newspaper circulation. It is difficult to identify omitted variables (demand, social development, education) that would be correlated with "other" circulation but not with English or Hindi circulation. The fact that we observe symmetric average and marginal media effects for two distinct shock response is also encouraging.

Our final effort is to confront head on the possibility that newspaper circulation may be endogenous or correlated with some other omitted variable that is trending 
over time in different states in a way that is correlated with government responsiveness. To deal with this convincingly would require an appropriate instrument for newspaper circulation. This is not very straightforward. However, as a robustness check on the importance of the media, we venture the possibility that sex specific literacy rates which reflect stocks of human capital in male and female populations may affect newspaper circulation without having an independent effect on responsiveness.

Adult literacy and in particular female adult literacy is closely correlated with newspaper circulation but does not directly influence government responsiveness in the areas of food distribution and calamity relief when we include it as a regressor. When we disaggregated newspaper circulation by language we found that literacy exerts a disproportionately strong influence on the distribution of newspapers not published in English or Hindi. This reflects the impact of literacy extending beyond elites and beginning to reach poorer segments of the Indian population thus creating demand for local language newspapers (see Jeffrey, 2000). We therefore have a story about investments in education affecting female and male adult literacy in different states which in turn drive the growth of newspapers and in particular the growth of regional newspapers.

Our finding of a positive and significant relationship between literacy and newspaper circulation is not surprising given that literacy embodies educational achievement and will affect both demand for newspapers and the ability of citizens to absorb information. Moreover, it may affect political development, for example by affecting the use of leaflet drops in electoral campaigns. Here, we experiment with the possibility that it drives newspaper circulation, without having a direct effect on responsiveness and therefore can be used as an instrument to check the robustness of our findings. Moreover, by using both male and female adult literacy, we are over-identified and can test whether our instruments belong in the second stage.

Table 6 presents results where male and female adult literacy rates have been used to instrument both total (columns (1) and (3)) and "other" (columns (2) and (4)) newspaper circulation. The $F$ tests for the first stage shown at the base of Table 6 confirm that there is a significant relationship between literacy and newspaper circulation and that this relationship is considerably stronger for "other" newspapers relative to total newspapers. With the exception of column (1) where our instruments do not pass the overidentification tests we find that instrumented newspaper circulation is positive and significant with instrumented "other" newspapers having a stronger impact on public food distribution and calamity relief than instrumented total newspaper circulation. These results are consistent with our uninstrumented results. In columns (2), (3) and (4) our instruments do pass standard overidentification tests and so pass muster on econometric grounds. The results presented in Table 6 therefore increase our confidence that newspaper circulation does make state governments in India more responsive to the concerns of poor and vulnerable citizens. The results are also consistent in suggesting that it is "other" newspapers published in local languages which are driving the results. 
Taken together, the results in Tables 3, 4, 5, and 6 are consistent with the idea that a range of political factors and development of press media do affect whether the concerns of poor and vulnerable citizens are reflected in social protection policy. Moreover, the pattern of results is similar across the two shock-response systems that we have studied and we observe both average and marginal effects. In contrast, economic factors which reflect the capacity of state governments to respond such as state income, urbanization and population density are only weakly associated with government responsiveness. Overall, the results are supportive of the notion that the development of political and social institutions is a prerequisite for responsive government.

\section{Concluding Comments}

An effectively functioning democracy has many facets. Among them is the possibility of creating incentives for elected officials to respond to citizens' needs. In this paper we have argued that political institutions as well as economic development affect government responsiveness. Elections provide an incentive for politicians to perform which can be enhanced by development of the media. Through this mechanism we would expect responsiveness of the government to salient issues such as crisis management to be greater where the media is more developed.

This allows us to revisit a literature which examines the importance of the media in famine relief policy (see Ram, 1991). Perhaps the most famous pronouncement on this subject was in Amartya Sen's 1981 Coromandel lecture published as Sen (1984). He observes that:

"India has not had a famine since independence, and given the nature of Indian politics and society, it is not likely that India can have a famine even in years of great food problems. The government cannot afford to fail to take prompt action when large-scale starvation threatens. Newspapers play an important part in this, in making the facts known and forcing the challenge to be faced." page 84 .

This view has now become received wisdom and is rarely questioned. ${ }^{31}$

Our results are consistent with this assessment. However, they highlight how a number of other factors, including turnout, political competitiveness, polarization and the timing of elections affect how governments respond. In addition, the results highlight the importance of local language newspapers in transmitting information. Therefore it would appear that the introduction of representative democracy and the development of a free and independent regional presses were key events in terms of ensuring some protection for vulnerable citizens. ${ }^{32}$

\footnotetext{
${ }^{31}$ See Bhagwati [1995] for a dissenting voice.

${ }^{32} \mathrm{On}$ the newspaper revolution and the rise of local language newpapers in the post-Indpendence era see Jeffrey (2000).
} 
There is scope for further work that tries to link government policy to media development, especially in developing countries. In an Indian context, there may be other policies that respond to media development. More broadly, our results also underline the potential importance of the development of civil society, of which the media is a key branch, to an effectively functioning democracy. The formal institutions of political competition (such as open elections) are not sufficient to deliver a responsive government unless voters have the real authority to discipline poorly functioning incumbents. This requires voters to have the necessary information. 


\section{R eferences}

[1] Ahluwalia, Deepak, [1993], "Public Distribution of Food in India: Coverage, targeting and leakages," Food Policy, 18 (1), 33-54.

[2] Alesina, Alberto, Reza Baqir and William Easterly, [1999], "Public Goods and Ethnic Divisions," Quarterly Journal of Economics, 114(4), 1243-1284.

[3] Banik, Dan, "India's Freedom from Famine: A Case Study of Kalahandi," typescript.

[4] Besley, Timothy J. and Anne C. Case, [1995b], "Does Political Accountability Affect Economic Policy Choices? Evidence From Gubernatorial Term Limits, Quarterly Journal of Economics 110(3), 769-98.

[5] Besley, Timothy and Stephen Coate, [2000], "Elected versus Appointed Regulators: Theory and Evidence," typescript.

[6] Besley, Timothy and Robin Burgess, [2000], "Land Reform, Poverty Reduction and Growth: Evidence from India," Quarterly Journal of Economics, 115(2), 389-430.

[7] Bhagwati, Jagdish, [1995], "The New Thinking on Development," Journal of Democracy, 6 (4), 50-64.

[8] Brians, Craig Leonard and Martin P. Wattenberg, [1996], "Campaign Issue Knowledge and Salience: Comparing Reception from TV Commercials, TV News and Newspapers," American Journal of Political Science, 40 (1), 172-193.

[9] Dreze, J. [1991], Famine Prevention in India in Dreze, J. and Sen. A. The Political Economy of Hunger Vol 2 (Oxford: Oxford University Press)

[10] Dreze, Jean and Amartya Sen, [1989], Hunger and Public Action (Oxford, Clarendon Press)

[11] Dreze, Jean and Amartya Sen, [1995], India: Economic Development and Social Opportunity (Oxford, Clarendon Press)

[12] Holbrook, Thomas M. and Emily Van Dunk, [1993], "Electoral Competition in the American States," American Political Science Review, 87(4), 955-962.

[13] Key, V.O., [1950], Southern Politics in State and Nation, New York : A.A. Knopf.

[14] Jeffrey, Robin [2000], India's Newspaper Revolution (London, Hurst and Company) 
[15] La Ferrara, E. [1999] "Inequality and Participation: Theory and Evidence from Rural Tanzania" mimeo Department of Economics, Bocconi University

[16] Miguel, Edward, [1999], "Ethnic Diversity and School Funding in Kenya" mimeo Department of Economics, Harvard.

[17] Mondak, Jeffrey J., [1995], "Newspapers and Political Awareness," American Journal of Political Science, 39 (2),. 513-527.

[18] Narayan and Pritchett, [1997], "Cents and Sociability: Household Income and Social Capital in Rural Tanzania" mimeo World Bank

[19] Ozler, Berk, Gaurav Datt and Martin Ravallion, [1996], "A Data Base on Poverty and Growth in India" mimeo World Bank.

[20] Pande, Rohini, [1999], "Minority Representation and Policy Choices: The Significance of Legislator Identity," mimeo Department of Economics, Columbia University.

[21] Ram, N. (1991): An Independent Press and Anti-Hunger Strategies: The Indian Experience in Dreze, J. and Sen. A. The Political Economy of Hunger Vol 1 (Oxford: Oxford University Press)

[22] Sen, A. [1981], Poverty and Famines, (Oxford: Oxford University Press)

[23] Sen, Amartya, [1984], "Food Battles: conflicts in the access to food," Food and Nutrition, 10(1), 81-89.

[24] Stromberg, David, [2000], "Radio's Impact on the New Deal," mimeo, Department of Econimics, IES, Stockholm. 


\section{Appendix: Proof of Proposition 1}

First, we show that the proposed pattern of responsiveness is optimal for the incumbent. Consider the case of a type $L$ incumbent - the analysis for a type $R$ is symmetric. If the cost shock is $c_{L}$, and being responsive results in support from an extra $\left(m+(1-m) \beta_{1}\right) \gamma_{v}^{R}$ voters then he will respond if and only if

$$
\begin{aligned}
& {\left[1-H\left(-\left(\gamma_{L}-\gamma_{H}\right)-\left(m+(1-m) \beta_{1}\right) \gamma_{v}^{R}\right)\right] \phi_{L L}+} \\
& H\left(-\left(\gamma_{L}-\gamma_{H}\right)-\left(m+(1-m) \beta_{1}\right) \gamma_{v}^{R}\right) \phi_{L R}-\beta_{1} c_{L} \\
& {\left[1-H\left(-\left(\gamma_{L}-\gamma_{H}\right)\right)\right] \phi_{L L}+H\left(-\left(\gamma_{L}-\gamma_{H}\right)\right) \phi_{R L} }
\end{aligned}
$$

which reduces to

$$
\Gamma_{L}\left(\left(m+(1-m) \beta_{1}\right) \gamma_{v}^{R}\right) \lambda>\beta_{1} c_{L}
$$

recalling that $\lambda=\phi_{L L}-\phi_{L R}$. It is clear that the incumbent will not respond when the cost shock is $c_{H}$ since $\Gamma_{L}\left(\left(m+(1-m) \beta_{1}\right) \gamma_{v}^{R}\right) \lambda<\lambda<\beta_{1} c_{L}$ for all $\beta \in[\underline{\beta}, 1]$.

We now show that the incumbent's is consistent with the assumed voting behavior which depends upon voters' updating. A citizen who observes that an incumbent has been responsive will update the probability that he is good to

$$
\frac{p}{p+\rho(1-p)} \text {. }
$$

Hence, we will support this incumbent against following his ideological preference if $p\left[\frac{(1-p)(1-\rho)}{p+\rho(1-p)}\right]>\frac{2 \lambda}{(1+\underline{\beta}) f}$ which is assumption 1 . To see that the condition is also necessary, observe that if $\Gamma_{L}\left(\left(m+(1-m) \beta_{1}\right) \gamma_{v}^{R}\right) \lambda<\beta_{1} c_{L}$ then the incumbent will prefer not to be responsive even if the cost shock is $c_{L}$. 


\section{Data A ppendix}

The data used in the paper come from a wide variety of sources. ${ }^{33}$ They cover the sixteen main Indian states listed in Table 1 and span the period 1958-1992. Haryana split from the state of Punjab in 1965. From this date on, we include separate observations for Punjab and Haryana.

Shocks: Our measure of food shortage (total food grain production measured in tonnes) comes from the Bulletin on Food Statistics, Ministry of Food and Agriculture, Directorate of Economics and Statistics, Government of India. To capture the nonlinear relationship between food production and public food distribution we transform this measure into a "food shock" indicator variable which is equal to one to one if food production in that year is below the state's sample median, and is zero otherwise. To deal with problems of collinearity, the food shock variable that we interact with media and political variables is the annual deviation of food grain production per capita from the state specific median value for the period 1958-1992. Our measure of flood shocks (real per capita value of crops affected by floods measured in rupees) comes from the Central Water Commission, Government of India and is available on an annual basis.

Government Responses: Public distribution of food grains measured in tonnes and expressed in per capita terms is our measure of how state governments respond to food shortages caused by droughts and other natural shocks. This data comes form the Bulletin on Food Statistics, Ministry of Food and Agriculture, Directorate of Economics and Statistics, Government of India. Calamity relief expenditure expressed as a share of net state domestic income is our measure of how state governments respond to flood shocks. This data which forms part of the social expenditure series in state expenditure accounts is published on an annual basis in the Reserve Bank of India Bulletin, Reserve Bank of India, Bombay, India.

Political Variables: Data on electoral turnout in state elections, which take place on average every four years, comes from Butler, Lahiri and Roy (1991) India Decides : Elections 1952-1991. (New Delhi : Aroom Purie for Living Media, India). Using the same data source, we construct a measure of political competitiveness by taking the absolute difference between the proportion of seats occupied by the Congress party (which has the been the dominant party over the period) and the proportion occupied by its main competitor(s). An Appendix Table provides a picture of the nature and timing of political competition in the sixteen main Indian states. As can seen from the table Congress, which has been the dominant political force in India, has been in competition with a number of other political groupings over the period. The main

\footnotetext{
${ }^{33}$ Our analysis has been aided by Ozler, Datt and Ravallion [1996] which collects published data on poverty, output, wages, price indices and population to construct a consistent panel data set on Indian states for the period 1958 to 1992. We are grateful to Martin Ravallion for providing us with this data. To these data, we have added information on newspapers, political representation and public policies pursued by states.
} 
political threat over the period has come from the Janata grouping of parties. In six states, Andra Pradesh, Assam, Jammu \& Kashmir, Orissa, Punjab and Tamil Nadu, Congress has also been competing with state-specific Regional parties. In three states, Madhya Pradesh, Rajasthan and Uttar Pradesh, Congress has in competition with the Bharatiya Janata Party which has a non-secular Hindu orientation and has been growing in importance over time. In two states, Kerala and West Bengal, Congress has been competing for political power over the period with Hard Left parties. ${ }^{34}$ We also investigate how the timing of elections influences responsiveness by constructing an election dummy, equal to one if it is an election or pre-election year in a given state. Finally, the fraction of the population classified as scheduled caste or scheduled tribe is our measure of caste polarization (see Pande, 1999). This information comes from the 1951, 1961, 1971, 1981 and 1991 censuses (Census of India, Registrar General and Census Commissioner, Government of India) and has been interpolated between census years.

M edia Variables:Our main media penetration variable is the average number of copies of newspapers/periodicals sold or distributed free per publishing day and comes from Press in India, Annual Report of the Registrar of Newspapers for India, Ministry of Information and Broadcasting, Government of India. This information is also available from the same source broken down by language and we have constructed three groupings: English, Hindi and "other" which includes newspapers/periodicals published in Assamese, Bengali, Gujarati, Kannada, Kashmiri, Konkani, Malayalam, Marathi, Manipuri, Nepali, Oriya, Punjabi, Sanskrit, Sindhi, Tamil, Telugu and Urdu.

Economic Variables:The primary source for data on state income is an annual government publication Estimates of State Domestic Product (Department of Statistics, Department of Statistics, Ministry of Planning). The primary source for the Consumer Price Index for Agricultural Laborers (CPIAL) and Consumer Price Index for Industrial Workers (CPIIW) which are used to deflate agricultural and nonagricultural components of state domestic product respectively is a number of Government of India publications which include Indian Labour Handbook, the Indian Labour Journal, the Indian Labour Gazette and the Reserve Bank of India Report on Currency and Finance. Ozler, Datt and Ravallion (1996) have further corrected CPIAL and CPIIW to take account of inter-state cost of living differentials and have also adjusted CPIAL to take account of rising firewood prices. Using their data allows us to put together a consistent and complete series on real total state income for the period 1960 to 1992 . Our measures of urbanization and population density are respectively the ratio of urban to total population and total state population divided by state land area. Population information comes from the 1951, 1961, 1971, 1981 and 1991 censuses (Census of India, Registrar General and Census Commissioner, Government of India) and has been interpolated between census years.

\footnotetext{
${ }^{34}$ See the Appendix Table for a definition of what parties are included under each of these groupings.
} 
Literacy: Literacy data broken down by gender comes from the 1951, 1961, 1971, 1981 and 1991 Indian censuses (Census of India, Registrar General and Census Commissioner, Government of India) and has been interpolated between census years. 
TABLE 1

\begin{tabular}{|c|c|c|c|c|c|c|c|c|c|c|c|}
\hline State & $\begin{array}{c}\text { Public Food } \\
\text { Distribution Per } \\
\text { Capita }\end{array}$ & $\begin{array}{c}\text { Calamity Relief } \\
\text { Expenditure Share } \\
\text { In Net State } \\
\text { Domestic Income }\end{array}$ & $\begin{array}{l}\text { Electoral } \\
\text { turnout in } \\
\text { state } \\
\text { elections }\end{array}$ & $\begin{array}{c}\text { Political } \\
\text { competitiveness }\end{array}$ & $\begin{array}{c}\text { Proportion Of } \\
\text { Scheduled } \\
\text { Caste/ Tribe In } \\
\text { Population }\end{array}$ & $\begin{array}{c}\text { Total Food } \\
\text { Grain } \\
\text { Production Per } \\
\text { Capita }\end{array}$ & $\begin{array}{c}\text { Real Per } \\
\text { Capita Value } \\
\text { of Crop } \\
\text { Affected } \\
\end{array}$ & $\begin{array}{c}\text { Newspaper/ } \\
\text { Periodical } \\
\text { Circulation Per } \\
\text { Capita }\end{array}$ & \begin{tabular}{l}
\multicolumn{1}{c}{ Other } \\
Newspapers \\
Circulation \\
Per Capita \\
\end{tabular} & $\begin{array}{c}\text { English } \\
\text { Newspapers } \\
\text { Circulation } \\
\text { Per Capita }\end{array}$ & $\begin{array}{c}\text { Hindi } \\
\text { Newspapers } \\
\text { Circulation } \\
\text { Per Capita }\end{array}$ \\
\hline $\begin{array}{l}\text { Andhra } \\
\text { Pradesh }\end{array}$ & $\begin{array}{l}11.615 \\
(9.012)\end{array}$ & $\begin{array}{c}0.414 \\
(0.357)\end{array}$ & $\begin{array}{l}68.719 \\
(3.515)\end{array}$ & $\begin{array}{c}0.558 \\
(0.113)\end{array}$ & $\begin{array}{c}0.191 \\
(0.021)\end{array}$ & $\begin{array}{l}185.851 \\
(18.448)\end{array}$ & $\begin{array}{c}8.252 \\
(14.937)\end{array}$ & $\begin{array}{c}0.029 \\
(0.011)\end{array}$ & $\begin{array}{l}0.0299 \\
(0.012)\end{array}$ & $\begin{array}{c}0.003 \\
(0.001)\end{array}$ & $\begin{array}{c}0.001 \\
(0.001)\end{array}$ \\
\hline Assam & $\begin{array}{l}24.681 \\
(7.632)\end{array}$ & $\begin{array}{c}0.395 \\
(0.296)\end{array}$ & $\begin{array}{c}62.978 \\
(11.530)\end{array}$ & $\begin{array}{c}0.552 \\
(0.241)\end{array}$ & $\begin{array}{c}0.209 \\
(0.026)\end{array}$ & $\begin{array}{l}150.402 \\
(12.973)\end{array}$ & $\begin{array}{c}10.802 \\
(11.729)\end{array}$ & $\begin{array}{l}0.0186 \\
(0.009)\end{array}$ & $\begin{array}{l}0.0135 \\
(0.007)\end{array}$ & $\begin{array}{c}0.003 \\
(0.002)\end{array}$ & $\begin{array}{c}0.001 \\
(0.001)\end{array}$ \\
\hline Bihar & $\begin{array}{l}11.110 \\
(6.001)\end{array}$ & $\begin{array}{c}0.249 \\
(0.246)\end{array}$ & $\begin{array}{l}51.764 \\
(5.903)\end{array}$ & $\begin{array}{c}0.454 \\
(0.136)\end{array}$ & $\begin{array}{c}0.222 \\
(0.0129)\end{array}$ & $\begin{array}{l}141.008 \\
(19.695)\end{array}$ & $\begin{array}{l}6.724 \\
(9.177)\end{array}$ & $\begin{array}{c}0.020 \\
(0.012)\end{array}$ & $\begin{array}{l}0.003 \\
(0.002)\end{array}$ & $\begin{array}{c}0.002 \\
(0.001)\end{array}$ & $\begin{array}{c}0.014 \\
(0.011)\end{array}$ \\
\hline Gujarat & $\begin{array}{l}18.576 \\
(10.512)\end{array}$ & $\begin{array}{c}0.485 \\
(0.462)\end{array}$ & $\begin{array}{l}55.906 \\
(5.678)\end{array}$ & $\begin{array}{l}0.568 \\
(0.253)\end{array}$ & $\begin{array}{c}0.212 \\
(0.008)\end{array}$ & $\begin{array}{l}118.376 \\
(30.598)\end{array}$ & $\begin{array}{c}3.599 \\
(6.285)\end{array}$ & $\begin{array}{c}0.054 \\
(0.008)\end{array}$ & $\begin{array}{c}0.053 \\
(0.009)\end{array}$ & $\begin{array}{c}0.002 \\
(0.001)\end{array}$ & $\begin{array}{c}0.0005 \\
(0.0004)\end{array}$ \\
\hline Haryana & $\begin{array}{c}9.813 \\
(4.081)\end{array}$ & $\begin{array}{c}0.190 \\
(0.127)\end{array}$ & $\begin{array}{l}67.431 \\
(5.108)\end{array}$ & $\begin{array}{l}0.541 \\
(0.237)\end{array}$ & $\begin{array}{c}0.193 \\
(0.003)\end{array}$ & $\begin{array}{l}467.687 \\
(99.335)\end{array}$ & $\begin{array}{c}8.799 \\
(15.280)\end{array}$ & $\begin{array}{l}0.020 \\
(0.005)\end{array}$ & $\begin{array}{c}0.004 \\
(0.002)\end{array}$ & $\begin{array}{c}0.004 \\
(0.004)\end{array}$ & $\begin{array}{c}0.013 \\
(0.005)\end{array}$ \\
\hline $\begin{array}{c}\text { Jammu \& } \\
\text { Kashmir }\end{array}$ & $\begin{array}{c}42.690 \\
(11.219)\end{array}$ & $\begin{array}{c}0.313 \\
(0.443)\end{array}$ & $\begin{array}{l}68.964 \\
(5.533)\end{array}$ & $\begin{array}{c}0.547 \\
(0.280)\end{array}$ & $\begin{array}{c}0.081 \\
(0.004)\end{array}$ & $\begin{array}{l}191.525 \\
(30.503)\end{array}$ & $\begin{array}{c}3.871 \\
(12.672)\end{array}$ & $\begin{array}{c}0.026 \\
(0.010)\end{array}$ & $\begin{array}{c}0.022 \\
(0.006)\end{array}$ & $\begin{array}{c}0.004 \\
(0.003)\end{array}$ & $\begin{array}{c}0.001 \\
(0.001)\end{array}$ \\
\hline Karnataka & $\begin{array}{l}15.368 \\
(7.774)\end{array}$ & $\begin{array}{c}0.175 \\
(0.256)\end{array}$ & $\begin{array}{l}63.372 \\
(5.825)\end{array}$ & $\begin{array}{l}0.587 \\
(0.216)\end{array}$ & $\begin{array}{c}0.167 \\
(0.030)\end{array}$ & $\begin{array}{l}180.081 \\
(24.588)\end{array}$ & $\begin{array}{c}0.485 \\
(1.844)\end{array}$ & $\begin{array}{c}0.047 \\
(0.014)\end{array}$ & $\begin{array}{c}0.045 \\
(0.012)\end{array}$ & $\begin{array}{c}0.008 \\
(0.002)\end{array}$ & $\begin{array}{c}0.001 \\
(0.001)\end{array}$ \\
\hline Kerala & $\begin{array}{c}45.979 \\
(19.337)\end{array}$ & $\begin{array}{c}0.178 \\
(0.348)\end{array}$ & $\begin{array}{l}77.572 \\
(3.772)\end{array}$ & $\begin{array}{l}0.152 \\
(0.123)\end{array}$ & $\begin{array}{c}0.103 \\
(0.007)\end{array}$ & $\begin{array}{c}54.886 \\
(10.324)\end{array}$ & $\begin{array}{c}3.607 \\
(7.715)\end{array}$ & $\begin{array}{c}0.151 \\
(0.060)\end{array}$ & $\begin{array}{c}0.162 \\
(0.064)\end{array}$ & $\begin{array}{c}0.004 \\
(0.003)\end{array}$ & $\begin{array}{c}0.001 \\
(0.001)\end{array}$ \\
\hline $\begin{array}{l}\text { Madhya } \\
\text { Pradesh }\end{array}$ & $\begin{array}{c}7.564 \\
(5.333)\end{array}$ & $\begin{array}{c}0.198 \\
(0.330)\end{array}$ & $\begin{array}{l}49.089 \\
(6.056)\end{array}$ & $\begin{array}{l}0.531 \\
(0.145)\end{array}$ & $\begin{array}{c}0.354 \\
(0.020)\end{array}$ & $\begin{array}{l}255.743 \\
(31.733)\end{array}$ & $\begin{array}{c}0.552 \\
(2.300)\end{array}$ & $\begin{array}{l}0.0225 \\
(0.017)\end{array}$ & $\begin{array}{l}0.0004 \\
(0.002)\end{array}$ & $\begin{array}{c}0.001 \\
(0.002)\end{array}$ & $\begin{array}{c}0.020 \\
(0.017)\end{array}$ \\
\hline Maharashtra & $\begin{array}{l}28.271 \\
(8.617)\end{array}$ & $\begin{array}{c}0.253 \\
(0.569)\end{array}$ & $\begin{array}{l}59.347 \\
(4.384)\end{array}$ & $\begin{array}{l}0.674 \\
(0.183)\end{array}$ & $\begin{array}{c}0.147 \\
(0.032)\end{array}$ & $\begin{array}{l}147.700 \\
(29.260)\end{array}$ & $\begin{array}{c}0.339 \\
(0.695)\end{array}$ & $\begin{array}{c}0.117 \\
(0.017)\end{array}$ & $\begin{array}{c}0.055 \\
(0.007)\end{array}$ & $\begin{array}{l}0.0480 \\
(0.015)\end{array}$ & $\begin{array}{c}0.016 \\
(0.008)\end{array}$ \\
\hline Orissa & $\begin{array}{l}10.944 \\
(5.082)\end{array}$ & $\begin{array}{c}0.580 \\
(0.727)\end{array}$ & $\begin{array}{l}44.939 \\
(7.490)\end{array}$ & $\begin{array}{l}0.413 \\
(0.255)\end{array}$ & $\begin{array}{c}0.385 \\
(0.008)\end{array}$ & $\begin{array}{l}222.052 \\
(31.243)\end{array}$ & $\begin{array}{c}5.604 \\
(8.093)\end{array}$ & $\begin{array}{c}0.016 \\
(0.010)\end{array}$ & $\begin{array}{c}0.018 \\
(0.011)\end{array}$ & $\begin{array}{c}0.001 \\
(0.0005)\end{array}$ & $\begin{array}{c}0.0004 \\
(0.0005)\end{array}$ \\
\hline Punjab & $\begin{array}{c}15.952 \\
(12.328)\end{array}$ & $\begin{array}{c}0.253 \\
(0.418)\end{array}$ & $\begin{array}{l}66.139 \\
(4.077)\end{array}$ & $\begin{array}{c}0.384 \\
(0.223)\end{array}$ & $\begin{array}{c}0.290 \\
(0.039)\end{array}$ & $\begin{array}{c}668.551 \\
(206.580)\end{array}$ & $\begin{array}{c}9.946 \\
(19.041)\end{array}$ & $\begin{array}{c}0.058 \\
(0.019)\end{array}$ & $\begin{array}{c}0.045 \\
(0.014)\end{array}$ & $\begin{array}{c}0.004 \\
(0.003)\end{array}$ & $\begin{array}{c}0.012 \\
(0.007)\end{array}$ \\
\hline Rajasthan & $\begin{array}{l}10.209 \\
(8.765)\end{array}$ & $\begin{array}{c}0.711 \\
(1.011)\end{array}$ & $\begin{array}{l}52.991 \\
(6.219)\end{array}$ & $\begin{array}{c}0.454 \\
(0.197)\end{array}$ & $\begin{array}{c}0.287 \\
(0.008)\end{array}$ & $\begin{array}{l}229.405 \\
(45.251)\end{array}$ & $\begin{array}{c}2.188 \\
(4.649)\end{array}$ & $\begin{array}{c}0.032 \\
(0.016)\end{array}$ & $\begin{array}{c}0.003 \\
(0.001)\end{array}$ & $\begin{array}{c}0.001 \\
(0.003)\end{array}$ & $\begin{array}{c}0.027 \\
(0.018)\end{array}$ \\
\hline Tamil Nadu & $\begin{array}{c}21.243 \\
(11.344)\end{array}$ & $\begin{array}{c}0.157 \\
(0.166)\end{array}$ & $\begin{array}{l}69.700 \\
(4.160)\end{array}$ & $\begin{array}{c}0.554 \\
(0.141)\end{array}$ & $\begin{array}{c}0.192 \\
(0.006)\end{array}$ & $\begin{array}{l}150.917 \\
(17.887)\end{array}$ & $\begin{array}{l}1.007 \\
(2.407)\end{array}$ & $\begin{array}{c}0.116 \\
(0.016)\end{array}$ & $\begin{array}{c}0.095 \\
(0.015)\end{array}$ & $\begin{array}{c}0.018 \\
(0.005)\end{array}$ & $\begin{array}{c}0.004 \\
(0.004)\end{array}$ \\
\hline $\begin{array}{l}\text { Uttar } \\
\text { Pradesh }\end{array}$ & $\begin{array}{c}8.106 \\
(3.368)\end{array}$ & $\begin{array}{c}0.168 \\
(0.138)\end{array}$ & $\begin{array}{l}52.075 \\
(6.033)\end{array}$ & $\begin{array}{l}0.477 \\
(0.165)\end{array}$ & $\begin{array}{c}0.218 \\
(0.008)\end{array}$ & $\begin{array}{l}213.085 \\
(33.443)\end{array}$ & $\begin{array}{c}9.727 \\
(10.255)\end{array}$ & $\begin{array}{c}0.035 \\
(0.013)\end{array}$ & $\begin{array}{c}0.005 \\
(0.001)\end{array}$ & $\begin{array}{c}0.003 \\
(0.001)\end{array}$ & $\begin{array}{c}0.028 \\
(0.012)\end{array}$ \\
\hline TOTAL & $\begin{array}{c}19.774 \\
(15.191)\end{array}$ & $\begin{array}{c}0.315 \\
(0.468)\end{array}$ & $\begin{array}{c}60.955 \\
(10.793)\end{array}$ & $\begin{array}{c}0.492 \\
(0.224)\end{array}$ & $\begin{array}{c}0.221 \\
(0.081)\end{array}$ & $\begin{array}{c}218.182 \\
(154.980)\end{array}$ & $\begin{array}{c}5.245 \\
(10.526)\end{array}$ & $\begin{array}{c}0.053 \\
(0.045)\end{array}$ & $\begin{array}{c}0.034 \\
(0.041)\end{array}$ & $\begin{array}{c}0.008 \\
(0.013)\end{array}$ & $\begin{array}{c}0.011 \\
(0.013)\end{array}$ \\
\hline
\end{tabular}


TABLE 2

SHOCKS AND GOVERNMENT RESPONSIVENESS IN INDIA: 1958 - 1992

\begin{tabular}{|c|c|c|c|c|c|c|}
\hline \multirow{2}{*}{ Model } & \multicolumn{3}{|c|}{ public food distribution per capita } & \multicolumn{3}{|c|}{$\begin{array}{l}\text { calamity relief expenditure share } \\
\text { in net state domestic income }\end{array}$} \\
\hline & $(1)$ & (2) & (3) & (4) & $(5)$ & $(6)$ \\
\hline $\begin{array}{l}\text { total food grain production } \\
\text { per capita }\end{array}$ & $\begin{array}{l}-0.024 \\
(-2.96)\end{array}$ & & & $\begin{array}{c}0.0004 \\
(0.49)\end{array}$ & & \\
\hline food shock dummy & & & $\begin{array}{l}3.462 \\
(4.48)\end{array}$ & & & \\
\hline $\begin{array}{l}\text { real per capita value of } \\
\text { crop affected [CROP] }\end{array}$ & $\begin{array}{l}0.033 \\
(0.86)\end{array}$ & & & $\begin{array}{l}0.013 \\
(6.93)\end{array}$ & & $\begin{array}{l}0.013 \\
(6.79)\end{array}$ \\
\hline $0-25 \%$ food production & & $\begin{array}{l}5.301 \\
(2.51)\end{array}$ & & & & \\
\hline $25-50 \%$ food production & & $\begin{array}{l}4.277 \\
(2.03)\end{array}$ & & & & \\
\hline $50-75 \%$ food production & & $\begin{array}{l}2.579 \\
(1.22)\end{array}$ & & & & \\
\hline $75-100 \%$ food production & & $\begin{array}{l}0.110 \\
(0.05)\end{array}$ & & & & \\
\hline $0-25 \%$ CROP & & & & & $\begin{array}{l}-0.446 \\
(3.14)\end{array}$ & \\
\hline $25-50 \%$ CROP & & & & & $\begin{array}{l}-0.541 \\
(4.11)\end{array}$ & \\
\hline $50-75 \%$ CROP & & & & & $\begin{array}{l}-0.504 \\
(3.75)\end{array}$ & \\
\hline 75-100\% CROP & & & & & $\begin{array}{l}-0.348 \\
(2.53)\end{array}$ & \\
\hline state effects & YES & YES & YES & YES & YES & YES \\
\hline year effects & YES & YES & YES & YES & YES & YES \\
\hline Number of observations & 492 & 512 & 512 & 459 & 491 & 491 \\
\hline $\begin{array}{c}\text { F test } \\
(\mathrm{p} \text {-value })\end{array}$ & & $\begin{array}{c}7.67 \\
(0.00)\end{array}$ & & & $\begin{array}{c}2.91 \\
(0.034)\end{array}$ & \\
\hline adjusted R-squared & 0.72 & 0.72 & 0.71 & 0.22 & 0.20 & 0.22 \\
\hline
\end{tabular}

Notes: $t$ statistics in parentheses. See the Data Appendix for details on the construction and sources of the variables. Columns (2) and (5) contain dummies which measure whether the observation of food grain production or crop damage for a particular state and year is in the $0-25,25-50,50-75$ or 75-100 percentile of the state specific distribution of these variables. F tests for the equality of these four coefficients are reported at the bottom of columns (2) and (5) capture whether In column (3) the food shock dummy takes a value of 1 if food grain production per capita in a given year falls below the state specific median averaged over the 1958-1992 period and a value of 0 otherwise. 
TABLE 3

DETERMINANTS OF RESPONSIVENESS: BASIC RESULTS

\begin{tabular}{|c|c|c|c|c|}
\hline \multirow[b]{2}{*}{ Model } & \multicolumn{2}{|c|}{$\begin{array}{c}\text { public food } \\
\text { distribution per capita }\end{array}$} & \multicolumn{2}{|c|}{$\begin{array}{c}\text { calamity relief expenditure } \\
\text { in net state domestic } \\
\text { income share }\end{array}$} \\
\hline & (1) & (2) & (3) & (4) \\
\hline food shock dummy & $\begin{array}{l}3.641 \\
(4.28)\end{array}$ & $\begin{array}{l}3.548 \\
(4.24)\end{array}$ & & \\
\hline $\begin{array}{l}\text { real per capita value of } \\
\text { crop affected [CROP] }\end{array}$ & & & $\begin{array}{l}0.012 \\
(6.33)\end{array}$ & $\begin{array}{l}0.012 \\
(7.08)\end{array}$ \\
\hline $\begin{array}{l}\text { newspaper circulation } \\
\text { per capita }\end{array}$ & & $\begin{array}{l}94.30 \\
(3.41)\end{array}$ & & $\begin{array}{l}3.528 \\
(2.04)\end{array}$ \\
\hline turnout $[\mathrm{t}-1]$ & & $\begin{array}{l}-0.114 \\
(1.67)\end{array}$ & & $\begin{array}{l}0.003 \\
(0.97)\end{array}$ \\
\hline $\begin{array}{c}\text { political } \\
\text { competitiveness }\end{array}$ & & $\begin{array}{l}-4.981 \\
(2.86)\end{array}$ & & $\begin{array}{l}-0.087 \\
(0.69)\end{array}$ \\
\hline $\begin{array}{c}\text { proportion of } \\
\text { scheduled caste/tribe } \\
\text { in population }\end{array}$ & & $\begin{array}{l}-2.231 \\
(0.09)\end{array}$ & & $\begin{array}{l}-1.721 \\
(0.69)\end{array}$ \\
\hline $\begin{array}{c}\text { pre or election year } \\
\text { dummy }\end{array}$ & & $\begin{array}{l}2.754 \\
(2.70)\end{array}$ & & $\begin{array}{l}-0.013 \\
(0.30)\end{array}$ \\
\hline $\begin{array}{c}\log \text { net state domestic } \\
\text { income }\end{array}$ & $\begin{array}{l}5.271 \\
(1.04)\end{array}$ & $\begin{array}{l}4.952 \\
(0.97)\end{array}$ & $\begin{array}{l}-0.733 \\
(2.08)\end{array}$ & $\begin{array}{l}-0.785 \\
(2.10)\end{array}$ \\
\hline $\begin{array}{l}\text { ratio of urban to total } \\
\text { population }\end{array}$ & $\begin{array}{l}126.6 \\
(2.36)\end{array}$ & $\begin{array}{l}74.21 \\
(1.31)\end{array}$ & $\begin{array}{l}-0.206 \\
(0.12)\end{array}$ & $\begin{array}{l}-0.623 \\
(0.27)\end{array}$ \\
\hline population density & $\begin{array}{r}-10.73 \\
(0.57)\end{array}$ & $\begin{array}{l}-23.39 \\
(1.47)\end{array}$ & $\begin{array}{l}-0.195 \\
(0.30)\end{array}$ & $\begin{array}{r}-0.641 \\
(0.96)\end{array}$ \\
\hline state effects & YES & YES & YES & YES \\
\hline year effects & YES & YES & YES & YES \\
\hline $\begin{array}{c}\text { number of } \\
\text { observations }\end{array}$ & 476 & 471 & 491 & 486 \\
\hline adjusted $\mathrm{R}^{2}$ & 0.74 & 0.76 & 0.23 & 0.24 \\
\hline
\end{tabular}

Notes: $t$ statistics in parentheses. See the Data Appendix for details on the construction and sources of the variables. In columns (1) and (2) the food shock dummy takes a value of 1 if food grain production per capita in a given year falls below the state specific median averaged over the 1958-1992 period and a value of 0 otherwise. 
TABLE 4

POLITICS AND RESPONSIVENESS

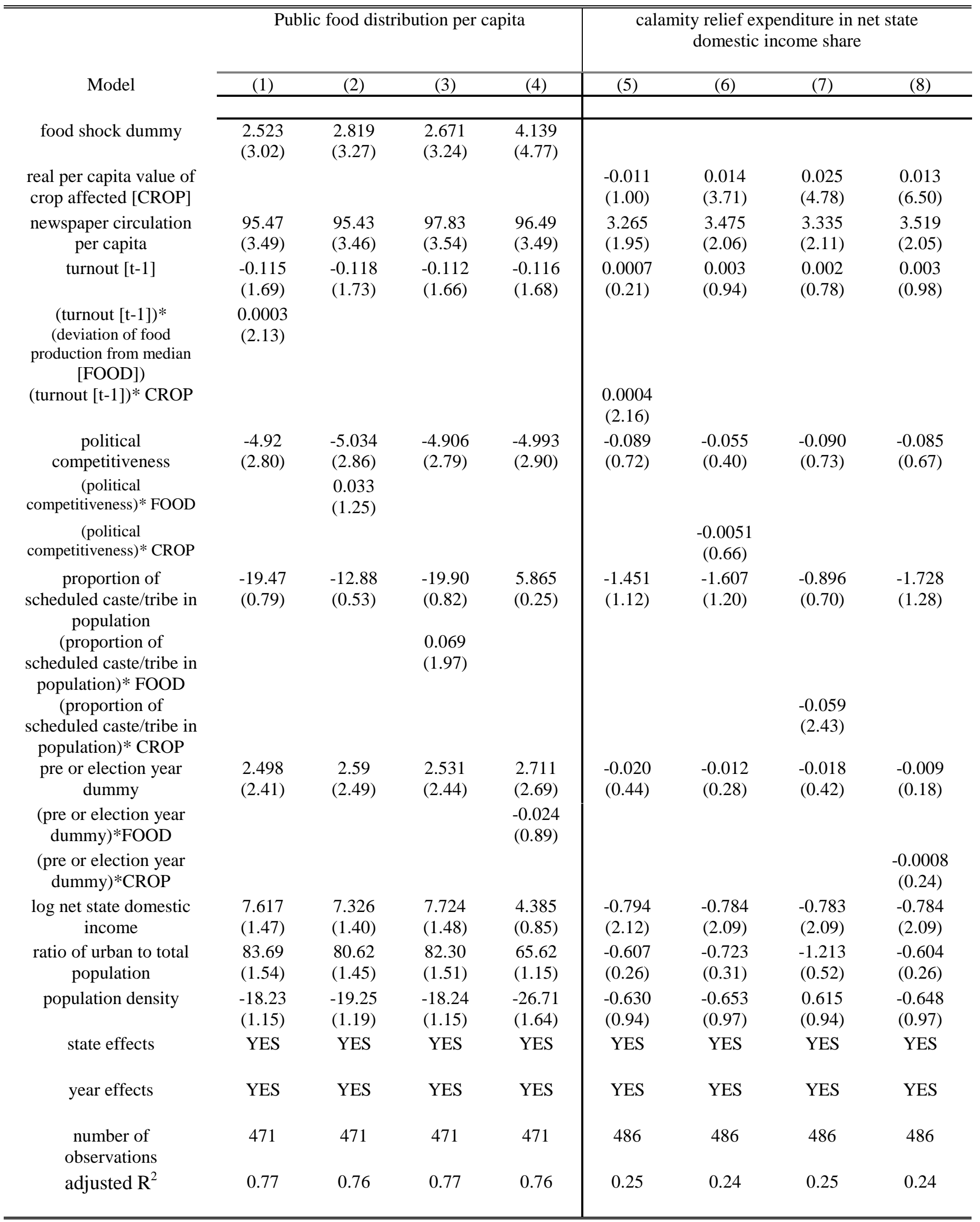

Notes: t statistics in parentheses. See the Data Appendix for details on the construction and sources of the variables. The food shock dummy takes a value of 1 if food grain production per capita in a given year falls below the state specific median averaged over the 1958-1992 period and a value of 0 otherwise. For the interaction terms the food shock variable (FOOD) we use is the annual deviation of food grain production per capita from the state specific median value for the period 1958-1992 
TABLE 5

NEWSPAPERS AND RESPONSIVENESS

Model

food shock dummy

real per capita value of crop affected

$$
\text { [CROP] }
$$

newspaper circulation per capita

(newspaper circulation per capita)* (deviation of food production from median [FOOD])

(newspaper circulation per capita)* CROP

English newspapers circulation per capita

Hindi newspapers circulation per capita

Other newspapers circulation per capita

(English newspapers circulation per capita)* FOOD

(Hindi newspapers circulation per capita)* FOOD

(Other newspapers circulation per capita)* FOOD

(English newspapers circulation per capita)* CROP

(Hindi newspapers circulation per capita)* CROP

(Other newspapers circulation per capita)* CROP

economic controls

political controls

state effects

year effects

number of observations

adjusted $\mathrm{R}^{2}$ public food distribution per capita

\begin{tabular}{c}
\hline$(1)$ \\
\hline 2.17 \\
$(2.66)$ \\
\\
\\
96.36 \\
$(3.54)$ \\
0.445 \\
$(4.23)$
\end{tabular}

96.36

(3.54)

(4.23)

2.66)

caplta

(2)

3.01

(3.58)

(3.58)

(4.

(3)

1.91 calamity relief expenditure share

in net state domestic income

(4)

4)

0.007

(2.46)

2.285

(1.81)

0.113

(2.34)

$\begin{array}{cc}61.18 & 41.76 \\ (0.68) & (0.48) \\ -57.87 & -45.82 \\ (1.23) & (1.00) \\ 118.8 & 122.7 \\ (3.49) & (3.49) \\ & -0.293 \\ & (0.33) \\ & 0.037 \\ & (0.05) \\ & 0.571 \\ & (2.58)\end{array}$

3.218

(0.68)

4.267

$-3.624$

(0.89)

(1.10)

$-4.105$

4.177

(1.18)

(2.23)

2.527

(1.88)

$\begin{array}{ccc}\text { YES } & \text { YES } & \text { YES } \\ \text { YES } & \text { YES } & \text { YES } \\ \text { YES } & \text { YES } & \text { YES } \\ \text { YES } & \text { YES } & \text { YES } \\ 471 & 467 & 467\end{array}$

$\begin{array}{ccc}\text { YES } & \text { YES } & \text { YES } \\ \text { YES } & \text { YES } & \text { YES } \\ \text { YES } & \text { YES } & \text { YES } \\ \text { YES } & \text { YES } & \text { YES } \\ 486 & 482 & 482 \\ 0.25 & 0.25 & 0.25\end{array}$

Notes: $t$ statistics in parentheses. See the Data Appendix for details on the construction and sources of the variables. The food shock dummy takes a value of 1 if food grain production per capita in a given year falls below the state specific median averaged over the 1958-1992 period and a value of 0 otherwise. For the interaction terms the food shock variable (FOOD) we use is the annual deviation of food grain production per capita from the state specific median value for the period 1958-1992. "Other" captures circulation of newspapers published in languages other than English or Hindi. 
TABLE 6

NEWSPAPERS AND RESPONSIVENESS: INSTRUMENTING WITH LITERACY

\begin{tabular}{|c|c|c|c|c|}
\hline & \multicolumn{2}{|c|}{$\begin{array}{l}\text { Public food distribution } \\
\text { per capita }\end{array}$} & \multicolumn{2}{|c|}{$\begin{array}{c}\text { Calamity relief expenditure } \\
\text { share } \\
\text { in net state domestic } \\
\text { income }\end{array}$} \\
\hline & $(1)$ & (2) & (3) & $(4)$ \\
\hline $\begin{array}{l}\text { food shock dummy } \\
\text { real per capita value of crop } \\
\text { affected [CROP] }\end{array}$ & $\begin{array}{c}2.66 \\
(2.22)\end{array}$ & $\begin{array}{c}2.10 \\
(1.96)\end{array}$ & $\begin{array}{l}0.009 \\
(4.02)\end{array}$ & $\begin{array}{l}0.010 \\
(5.23)\end{array}$ \\
\hline $\begin{array}{l}\text { newspapers circulation per } \\
\text { capita }\end{array}$ & $\begin{array}{l}201.5 \\
(0.92)\end{array}$ & & $\begin{array}{l}16.08 \\
(2.19)\end{array}$ & \\
\hline $\begin{array}{l}\text { other newspapers circulation } \\
\text { per capita }\end{array}$ & & $\begin{array}{l}236.2 \\
(2.51)\end{array}$ & & $\begin{array}{l}10.51 \\
(2.62)\end{array}$ \\
\hline turnout $[\mathrm{t}-1]$ & $\begin{array}{l}-0.088 \\
(0.99)\end{array}$ & $\begin{array}{l}-0.102 \\
(1.14)\end{array}$ & $\begin{array}{l}0.007 \\
(1.53)\end{array}$ & $\begin{array}{l}0.005 \\
(1.20)\end{array}$ \\
\hline political competitiveness & $\begin{array}{l}-2.850 \\
(1.34)\end{array}$ & $\begin{array}{l}-2.330 \\
(1.11)\end{array}$ & $\begin{array}{l}0.025 \\
(0.17)\end{array}$ & $\begin{array}{l}0.008 \\
(0.06)\end{array}$ \\
\hline $\begin{array}{l}\text { proportion of scheduled } \\
\text { caste/tribe in population }\end{array}$ & $\begin{array}{l}16.06 \\
(0.42)\end{array}$ & $\begin{array}{l}5.113 \\
(0.18)\end{array}$ & $\begin{array}{l}-0.706 \\
(0.47)\end{array}$ & $\begin{array}{l}-1.906 \\
(1.34)\end{array}$ \\
\hline pre or election year dummy & $\begin{array}{l}3.580 \\
(2.93)\end{array}$ & $\begin{array}{l}3.558 \\
(2.92)\end{array}$ & $\begin{array}{l}-0.023 \\
(0.42)\end{array}$ & $\begin{array}{l}-0.030 \\
(0.62)\end{array}$ \\
\hline log net state domestic income & $\begin{array}{l}1.845 \\
(0.25)\end{array}$ & $\begin{array}{l}-4.374 \\
(0.72)\end{array}$ & $\begin{array}{r}-0.774 \\
(2.00)\end{array}$ & $\begin{array}{l}-1.056 \\
(2.46)\end{array}$ \\
\hline $\begin{array}{l}\text { ratio of urban to total } \\
\text { population }\end{array}$ & $\begin{array}{l}37.39 \\
(0.22)\end{array}$ & $\begin{array}{c}0.252 \\
(0.002)\end{array}$ & $\begin{array}{l}-6.429 \\
(1.08)\end{array}$ & $\begin{array}{l}-3.144 \\
(0.87)\end{array}$ \\
\hline $\begin{array}{l}\text { population density } \\
\text { state effects }\end{array}$ & $\begin{array}{l}-40.88 \\
(0.83) \\
\text { YES }\end{array}$ & $\begin{array}{l}-57.56 \\
(2.04) \\
\text { YES }\end{array}$ & $\begin{array}{l}-2.578 \\
(1.38) \\
\text { YES }\end{array}$ & $\begin{array}{l}-1.680 \\
(1.37) \\
\text { YES }\end{array}$ \\
\hline year effects & YES & YES & YES & YES \\
\hline $\begin{array}{l}\text { F-test for first stage } \\
\quad(\text { Prob }>\text { F })\end{array}$ & $\begin{array}{l}30.94 \\
(0.00)\end{array}$ & $\begin{array}{l}34.38 \\
(0.00)\end{array}$ & $\begin{array}{c}3.96 \\
(0.00)\end{array}$ & $\begin{array}{c}4.52 \\
(0.00)\end{array}$ \\
\hline overidentification test $p$-value & 0.66 & 0.96 & 0.95 & 0.99 \\
\hline number of observations & 414 & 410 & 433 & 429 \\
\hline $\mathrm{R}^{2}$ & 0.77 & 0.77 & 0.23 & 0.33 \\
\hline
\end{tabular}

Notes: $t$ statistics in parentheses. See the Data Appendix for details on the construction and sources of the variables. The food shock dummy takes a value of 1 if food grain production per capita in a given year falls below the state specific median averaged over the 1958-1992 period and a value of 0 otherwise. In columns (1) and (2) newspaper circulation per capita is instrumented using male and female literacy rates for the population above 15 years of age which has been interpolated between census years. The $\mathrm{F}$ test for the joint significance of male and female literacy in the first stage regression explaining newspaper circulation is given at the base of the table. The overidentification test we employ is due to Sargan [1958]. The number of observations times the R-squared from the regression of the stage two residuals on the instruments is distributed $\chi^{2}(\mathrm{~T}+1)$ where $\mathrm{T}$ is the number of instruments. 
$\left.\Gamma_{L}\left(\beta\left(1-m_{1}\right)+m_{1}\right) \gamma_{v}{ }^{L}\right) \lambda$

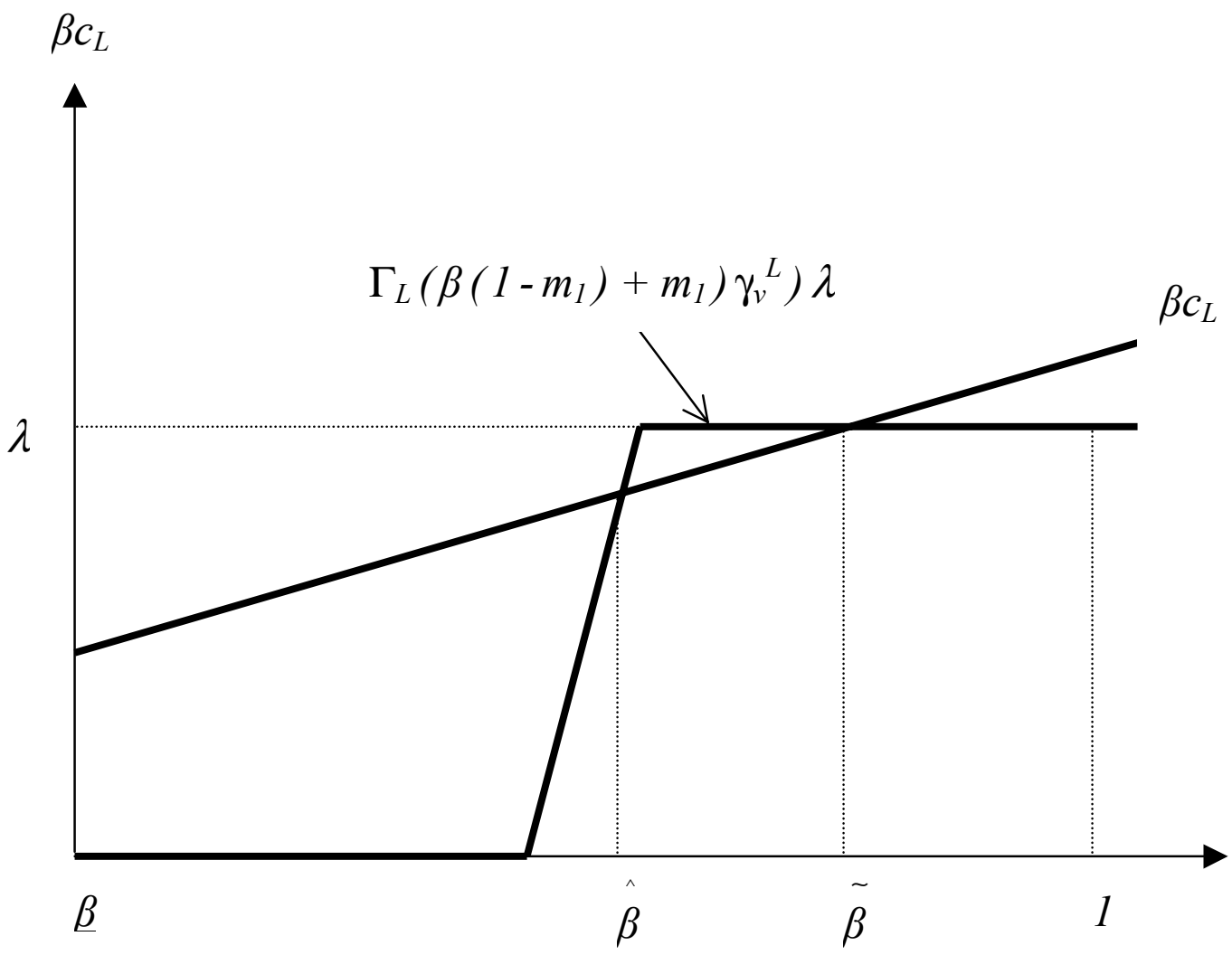

Figure 1

$\left.\Gamma_{L}\left(\beta\left(1-m_{1}\right)+m_{1}\right) \gamma_{v}{ }^{L}\right) \lambda$

$\beta c_{L}$

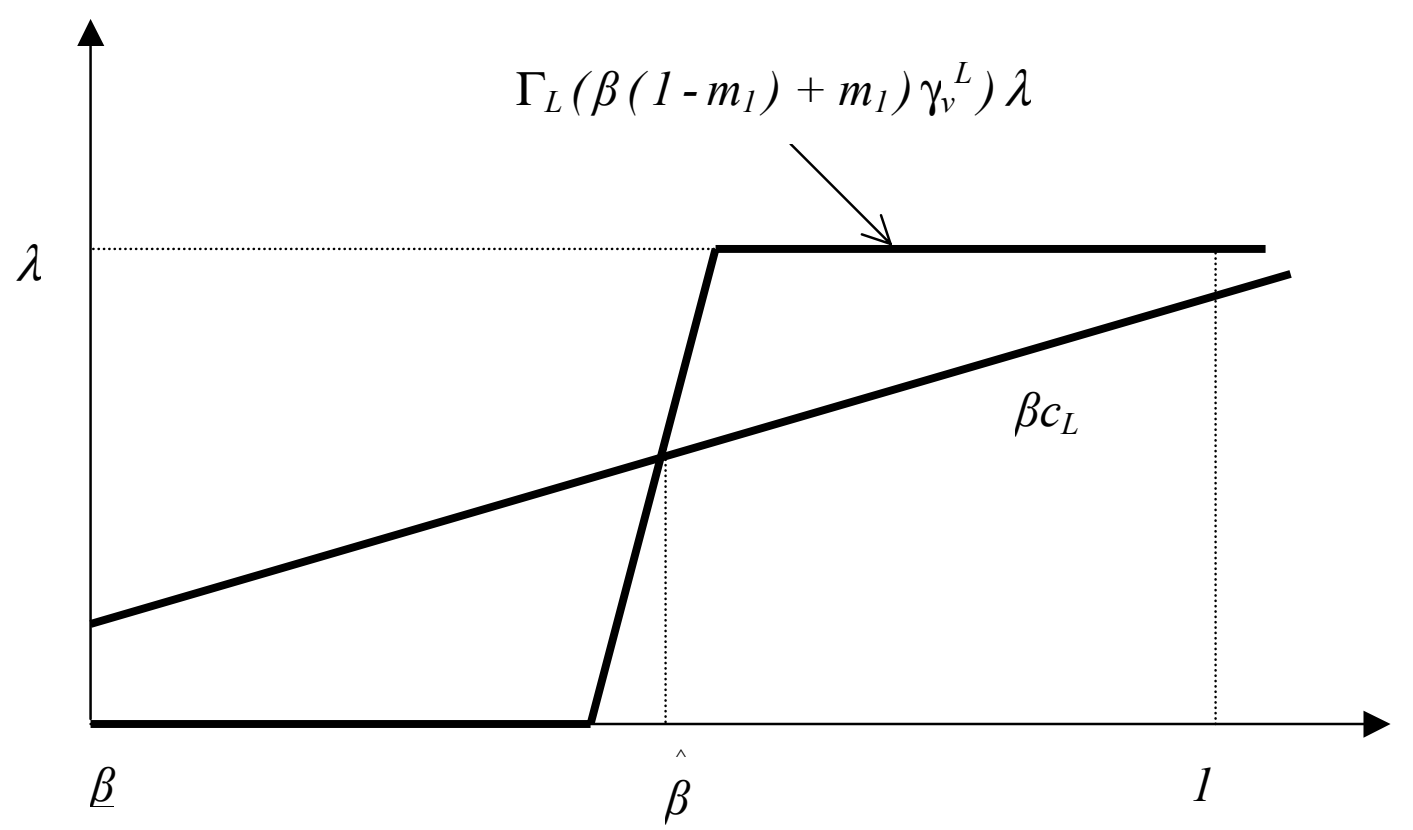

Figure 2 
Figure 3: VARIATIONS IN FOOD GRAIN PRODUCTION 1958-1992

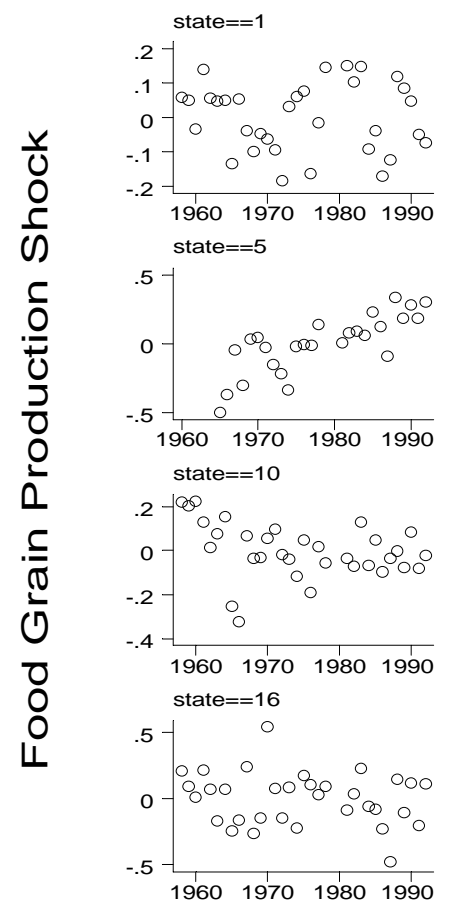

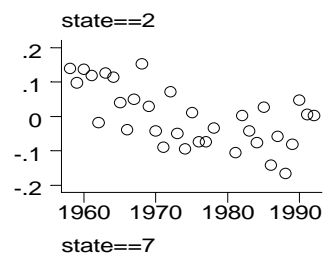
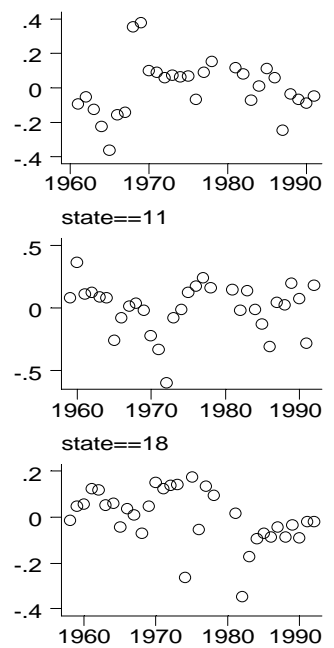
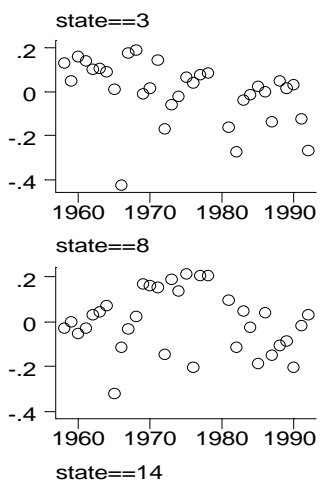
2 - $\infty \quad 0$
$0-\infty^{\infty} 8^{\infty}, 0000^{\circ}$
$\begin{array}{cccccc}0 & -2\end{array}-\begin{array}{ccccc}0 & 0 & 0 & 0 & 0 \\ 0 & 0 & 0 & 0 & 0\end{array}$
$-.4-2$
$\begin{array}{llll}1960 & 1970 & 1980 & 1990\end{array}$ state $==20$

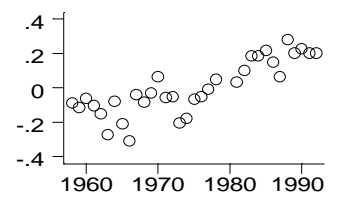

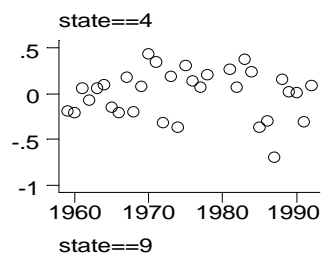
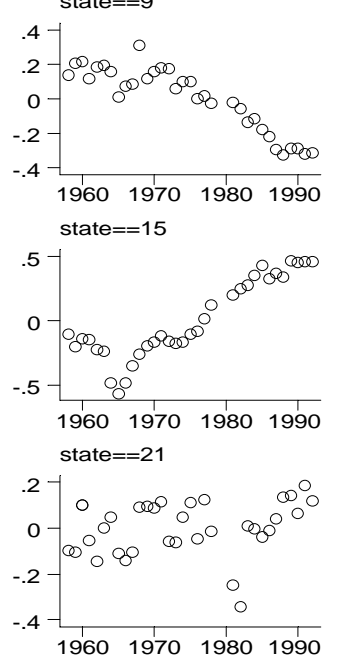

\section{year}


Figure 4: VARIATIONS IN VALUE OF CROPS DAMAGED BY FLOODS 1958-1992
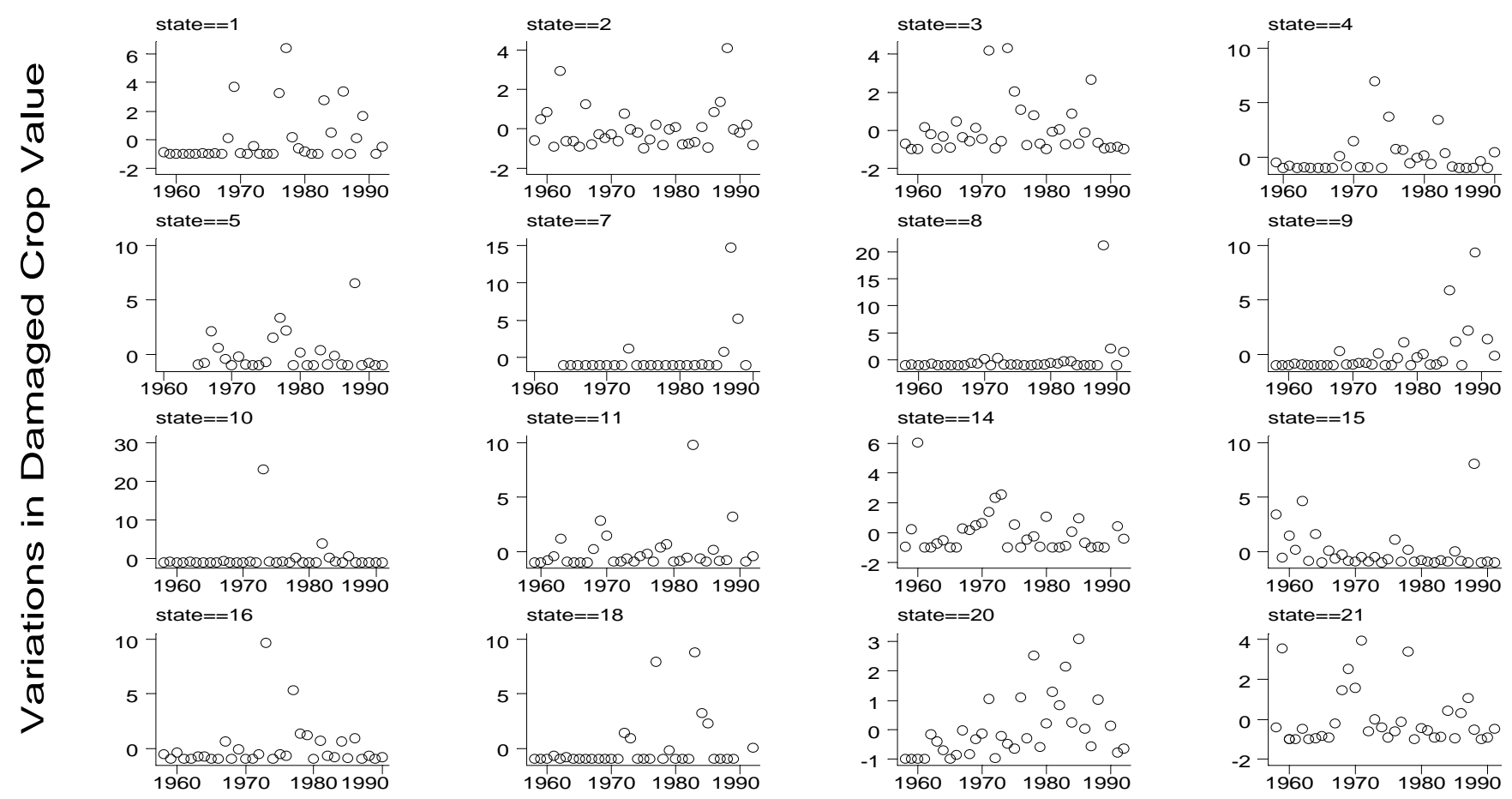

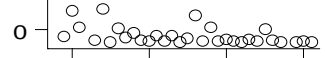
1960197019801990 state $==18$
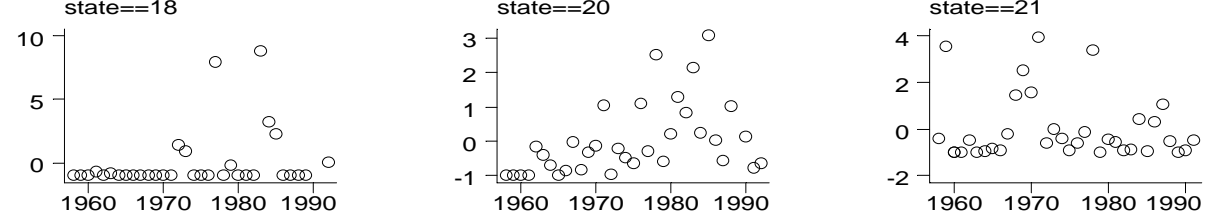
Figure 5: total newspaper/ PERIOdical CIRCulation PER CAPITA 1958-1992

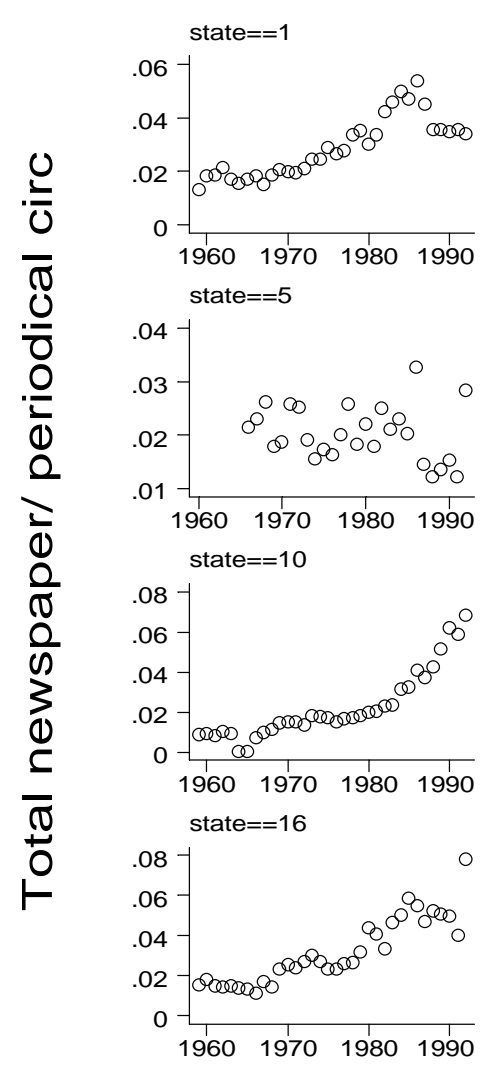

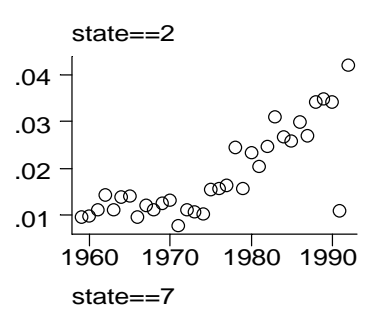
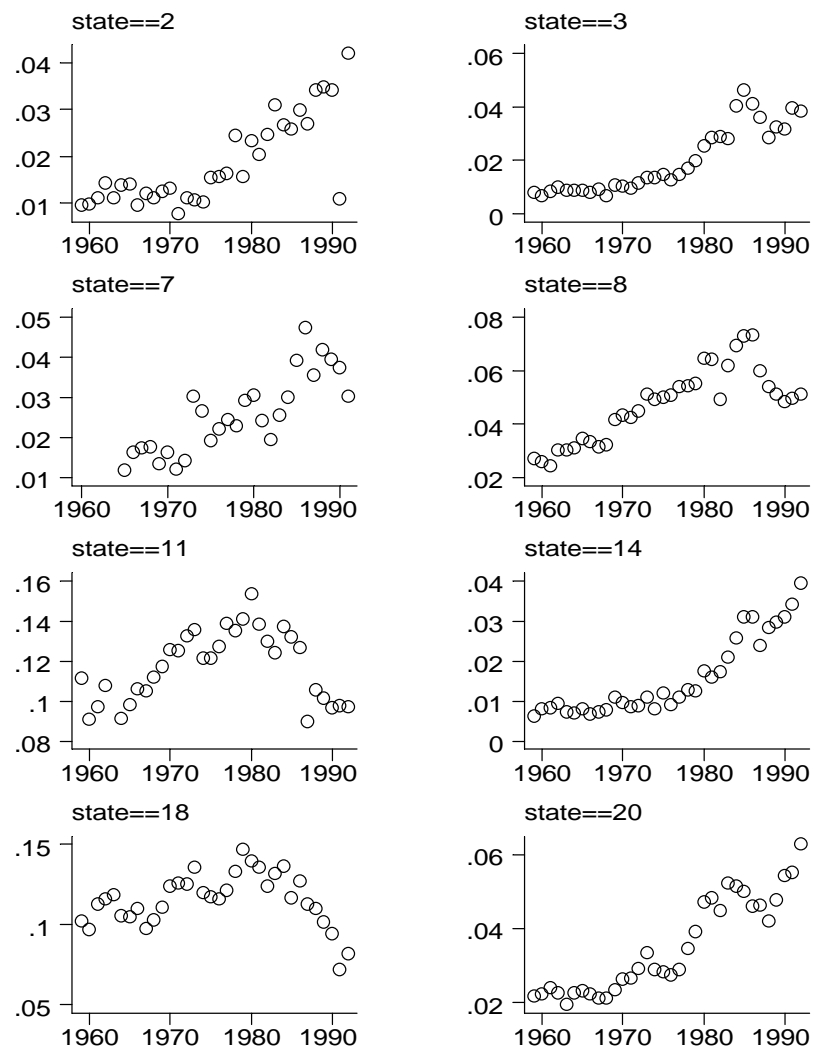

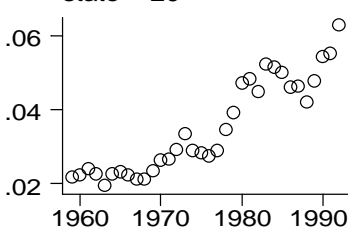

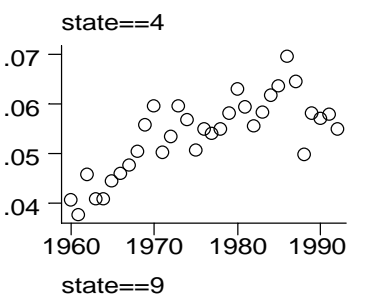
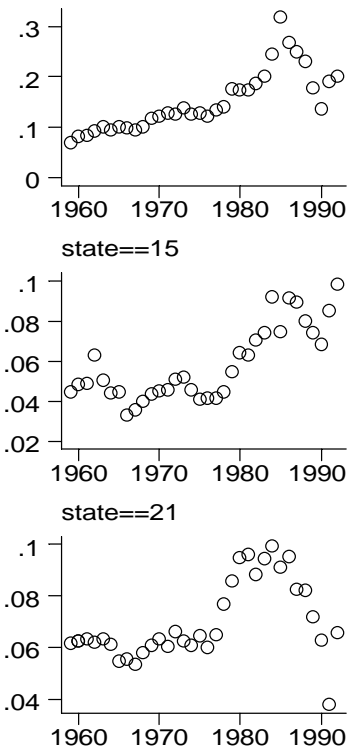

\section{year}


APPENDIX TABLE

POLTICAL COMPETITION IN INDIAN STATES 1958-1992

\begin{tabular}{c|c}
\hline \hline State & Nature and timing of political competition \\
\hline Andhra Pradesh & 1958-1983: Congress versus Janata Parties \\
1984-1992: Congress versus Regional Parties \\
Assam & 1958-1984: Congress versus Janata Parties \\
Bihar & 1985-1992: Congress versus Regional Parties \\
Gujarat & 1958-1992: Congress versus Janata Parties \\
Haryana & 1958-1992: Congress versus Janata Parties \\
J ammu \& Kashmir & 1958-1992: Congress versus Regional Parties \\
Karnataka & 1958-1992: Congress versus Janata Parties \\
Kerala & 1958-1992: Congress versus Hard Left Parties \\
Madhya Pradesh & 1958-1992: Congress versus Hindu Parties \\
Maharashtra & 1958-1992: Congress versus Janata Parties \\
Orissa & 1958-1976: Congress versus Regional Parties \\
1977-1992: Congress versus Janata Parties \\
Punjab
\end{tabular}

Notes: Congress Parties includes Indian National Congress, Indian National Congree Urs and Indian National Congress Socialist Parties. Janata parties includes Janata, Janata Dal and Lok Dal Parties. Hard Left Parties includes Communist Party of India and Communist Party of India Marxist Parties. Hindu Parties includes the Bharatiya Janata Party. Regional Parties include Telugu Desam, Asom Gana Parishad, Jammu \& Kashmir National Congress, Shiv Sena, Uktal Congress, Shiromani Alkali Dal and "other" Regional Parties, only one of which is active in a particular state. 